\title{
Empirical Analysis Towards the Effect of Social Media on Cryptocurrency Price and Volume
}

\author{
Tiran Rothman, \\ Management School, Wizo Haifa Academic College, Haifa, Israel \\ Chen Yakar, \\ Arison School of Business, Interdisciplinary Center (IDC), Herzliya, Israel \\ Doi:10.19044/esj.2019.v15n31p52～URL:http://dx.doi.org/10.19044/esj.2019.v15n31p52
}

\begin{abstract}
Bitcoin's value is highly dependent on the communities that use it. This network effect is true for all new technologies. Today's online communities are so large in population that both the Facebook user and Youtuber populations have surpassed the Chinese population. We take a big data approach using millions of samples of posts from Twitter, Telegram, and Reddit to study how and if social media platforms, the epitome of online communities, affect Bitcoin's price and volume as well as the price and volume of fifteen other top cryptocurrencies. We work in collaboration with Solume, a data centered fin-tech startup, as well as with Sentistrength, an opinion mining tool developed by researchers in the UK, to classify the sentiment of the millions of posts we study. We collected millions of posts related to 16 cryptocurrencies from November 2017 through August 2018 on an hourly basis and explore social media volume sentiment effect on these cryptocurrencies. Findings confirm that volumes of exchanged posts may predict the fluctuations of Bitcoin's price but mainly, they predict volume. We also find that Reddit and Telegram posts have greater impact on Bitcoin volume than Twitter. Results indicate that information about the use of social media platforms can assist in tracking real world behavior and may even predict real financial market trends.
\end{abstract}

Keywords: Behavioral Finance, Cryptocurrency, Social Media, Sentiment Analysis

\section{Introduction}

Bitcoin represents a radical change in financial systems, attracting a large number of users and a lot of media attention. The cryptocurrency was created by an unidentified programmer under the name Satoshi Nakamoto, who introduced it on October 31, 2008 and released it as open-source software 
in 2009 (Nakamoto, 2009). Bitcoin, as of May 15, 2019 represents about 58\% of the cryptocurrency market and is the first decentralized cryptocurrency of a growing family of more than 2000 cryptocurrencies. ${ }^{1}$ Bitcoin is different from traditional currencies because there is a limited amount of Bitcoins (21 million) and additional units cannot be created. The amount of Bitcoins that each user wallet holds is publicly visible because the Bitcoin protocol operates on a public ledger or list. This list is identical for the thousands of computers that update the amount of Bitcoin in each wallet. The fact that all lists are checked against one another to make sure they are identical, is what keeps the protocol so secure. One would have to tamper with the majority of lists dispersed on computers across the globe to make a fraudulent transaction. Banks have begun to use this same technology for easily transferring money from accounts across different banks but their protocol is private and the amount of currency in each account is not available to the public. Users who update the public Bitcoin ledger (termed mining) are rewarded with Bitcoin. Without a community constantly updating the public ledger, the security of the Bitcoin protocol would be compromised. This is why Bitcoin is categorized as a decentralized currency, i.e. it is governed by a community and not one central power. The second and third largest cryptocurrencies are Ethereum and Ripple, respectively representing $9.7 \%$ and $7.4 \%$ of the market. The 16 cryptocurrencies which we chose to study comprise over $86 \%$ of the market and provide a variety of different value propositions.

In this paper, we investigate 1) if the spread of cryptocurrency price and volume is related to the volumes of social media posts 2) how positive or negative sentiment in these posts affects cryptocurrency prices and 3) how and if the behavior of the cryptocurrencies themselves is correlated. Namely, we try to explore the ecosystem of cryptocurrencies in view of capital markets and in view of the relatively 'new world' of social impact on trading cryptocurrencies.

In addition to Twitter we chose to investigate other social media platforms such as Reddit and Telegram to validate cryptocurrency price correlation to social media platforms. We focus on Twitter as a leading social media platform and rich source of real-time information regarding current social trends and opinions, however, other social media platforms have started to emerge as a replacement to Twitter. For example, many members of the cryptocurrency community have chosen to aggregate around the Telegram platform due to its privacy centered branding as well as around Reddit forums. Following is a short explanation of each of the social media platforms that we retrieved our data from. While each platform is unique, they all allow for a feeling of connectedness and community.

${ }^{1}$ coinmarketcap.com 
Twitter is an online news and social networking site where people share short messages, up to 280 characters, called tweets. This type of activity is also known as microblogging. Twitter is the 9th most popular site in the US and the 6th most popular in the world (SimilarWeb). The platform is used by a variety of entities such as news channels, advertisers, celebrities, political figures, and anyone with thoughts to share. Users can follow other users and be updated whenever new content is tweeted. The platform numbers around 300 million monthly active users. In essence, twitter is similar to sending a text message to everyone in your community.

Reddit brands itself as the "front page of the internet". It is the 13th most popular site in the US and 18th most popular in the world (SimilarWeb). Reddit is simply a collection of forums that are generated by users. Each forum is called a "subreddit" and covers a unique topic. Subreddits are denoted with " $/ \mathrm{r} /$ " followed by the name of the forum. For example, /r/CryptoCurrency is a forum where people speak about news, trends, and predictions regarding the cryptocurrency ecosystem. Users can generate forums, post on them, and upvote or downvote posts thereby increasing or decreasing their visibility. In essence, Reddit is a community of well over 300 million monthly active users that share stuff online.

Telegram is a messaging app very similar to common messaging apps such as Facebook Messenger, WeChat, or WhatsApp. Telegram brands itself as a highly secure and encrypted platform. The company offers end-to-end encryption which means that data cannot be retrieved from Telegram's servers. Users can even choose to set self-destruct timers on messages shared that range from two seconds to one week. Telegram can be used in two ways: 1) Chat 2) Channel. Chat is the traditional pair or group dialogue used by other messaging apps. In channel format, only an author broadcasts messages that their community follows. In addition, Telegram has an added third-party layer called Bots. Bots are pieces of software that can be used to interact with Telegram in a variety of ways. They can perform a simple conversation or act as a search engine or even as a problem solving machine. The telegram community numbers a few hundred million monthly active users, similar to Twitter and Reddit. In essence, it is a messaging app which values privacy and that has advanced capabilities such as channels and bots.

While there are several studies that explore Twitter as a possible predictor of market trends, as far as we know, few have explored the correlation of other social media platforms to cryptocurrency market activity. Bollen (2010) showed that combining information on Wall Street with millions of tweets and posts makes it possible to anticipate financial performance. The analysis of tweets made by Bollen would have had an $87 \%$ chance to successfully predict stock prices 3 or 4 days in advance. Rao and Srivastava (2012) investigate the complex relationship between tweets 
(bullishness, volume, agreement etc) and financial market instruments (volatility, trading volume, and stock price). Mai and Hranac (2013) examine predictive relationships between social media and Bitcoin returns by considering the relative effect of different social media platforms (internet forums vs. microblogs such as Twitter) and the dynamics of the resulting relationships using models that check for interdependencies such as vector autoregressive and vector error correction models.

In the following section we describe the literature overview of cryptocurrencies and social media; in section 3 we explore methodology we use to investigate the connection between the two; section 4 describes the data and findings and then we discuss the results on section 5.

\section{Literature overview}

The literature on cryptocurrencies was initially dominated by studies on the safety, ethical and legal aspects of Bitcoin. Recently, some literature has examined Bitcoin from an economic viewpoint. Selgin (2015) argued that investors have employed Bitcoin as currency as well as for investment purposes, although, they claimed that Bitcoin should be seen as a speculative commodity rather than a currency. Dwyer (2015) finds that the average monthly volatility of Bitcoin is higher than that for gold or a set of foreign currencies, and the lowest monthly volatilities for Bitcoin are less than the highest monthly volatility for gold and currencies.

Cheah and Fry (2015) argue that if Bitcoin were a true unit or account, or a form of store of value, it would not display such volatility expressed by bubbles and crashes. Cheung et al (2015) show the existence of bubbles in the bitcoin market over the period and find a number of short-lived bubbles but also three huge bubbles, the last of which led to the demise of the Mt Gox exchange. Brière et al (2015) show that Bitcoin offers significant diversification benefits for investors while Dyhrberg (2016a; 2016b) show that Bitcoin has similar hedging capabilities as gold and the dollar, and as such can be employed for risk management.

Fry and Cheah (2016) develop a model to reveal that Bitcoin and Ripple are characterized by negative bubbles. Bouri et al. (2017) scrutinize hedge and safe haven properties of Bitcoin vis-'a-vis several stock, bonds and currency indices around the world. Its main finding is that the cryptocurrency is only useful as a diversifier device, but not as a hedge instrument. Finally, Balcilar et al. (2017) detect nonlinearities in the return-volume relationship, which allfows for return prediction. Rothman (2018) explored the digital coins eco-system correlations based on an hourly time interval. The findings show that bitcoin price and volume is not correlated with most of the traded digital coins while several digital coins are highly and significantly correlated with other coins. 
Analyzing cryptocurrenies based on social media, rich source of real-time information regarding current social trends and opinions has been investigated by some researchers. Bollen (2010) showed that combining information on Wall Street with the millions of Tweets and posts makes possible to anticipate financial performance. The analysis of Tweets made by Bollen would have had $87 \%$ of chance to successfully predict prices of the stock, 3 or 4 days in advance. Rao and Srivastava (2012) investigate the complex relationship between tweet board literature (like bullishness, volume, agreement etc) with the financial market instruments (like volatility, trading volume and stock price). Mai and Hranac (2013) examine predictive relationships between social media and Bitcoin returns by considering the relative effect of different social media platforms (Internet forum vs. microblogging) and the dynamics of the resulting relationships using vector autoregressive and vector error correction models.

\section{Methodology}

\subsection{Sentiment Analysis}

In recent years, there is a wide collection of research surrounding machine learning techniques that extract and identify subjective information in texts. This area is known as sentiment analysis or opinion mining. Sentiment techniques are able to extract indicators of public mood directly from social media content. Similar to Go et al. (2009) that affirmed the strength of sentiment analysis applied to the Twitter domain by using machine learning techniques to classifying the sentiment of tweets, we chose to use automated sentiment analysis techniques to identify the sentiment of tweets regarding Bitcoin.

Since the goal of this research is neither to develop a new sentiment analysis technique nor to improve an existing one, we use "SentiStrength", a tool developed by a team of researchers in the UK that demonstrated accurate outputs (see Kim, 2009, Thelwall et al., 2013, Thelwall 2017). SentiStrength estimates the degree of positive and negative sentiment in short texts ${ }^{2}$. It is based on a "dictionary" of sentiment related words, each associated with a weight that contributes to conclusive sentiment strength.

\subsection{Empirical framework}

We collected millions of posts related to all 16 cryptocurrencies under investigation: Bitcoin, Bitcoin Cash, Cardano, Dash, EOS, Ethereum, KyberNetwork, Litecoin, Monero, NEO, Ripple, Storm, TRON, Verge, Walton, and ZenCash (rebranded as Horizen) from November 2017 through August 2018 on an hourly basis. This period of time is especially telling because it is exactly

\footnotetext{
${ }^{2}$ http://sentistrength.wlv.ac.uk/
} 
the time when Bitcoin prices began to shoot up towards $\$ 20,000$ as well as the time when they dropped drastically through the majority of 2018 . Tweets for example, containing "\#Bitcoin” or "@bitcoin” are easily retrieved using Twitter's Application Programming Interface (API). ${ }^{3}$ We matched posts to intra-day prices and volumes in order to create a fundamental database. We then run the SentiStrength tool to determine the sentiment of posts to add another layer of information to the database.

With millions of Twitter posts given as an input, the system assigned a score to each post: 1 if the post was positive; -1 if the post was negative; 0 if the post was neutral. We also pull volume data regarding the amount of posts made on Twitter, Telegram, and Reddit on an hourly basis. This is termed "social volume" and can be retrieved from Solume, a Fintech start-up, that measures social volume where Twitter, Telegram and Reddit have equal weight and the output that Solume provides is both the volume of posts and the direction that a market is headed based on the activity on these platforms. ${ }^{4}$

In order to analyze the data, we use stationarity analysis which has high importance in its ubiquity in time series analysis, making the ability to understand, detect and model time series analysis (Nelson and Plosser, 1982). We then use the Engle and Granger (1987) cointegration approach to assess whether there is a long-run relationship between social media volume and cryptocurrencies prices and volume. We then ascertain the direction of causality between the two series using the error correction methodology of Engle and Granger (1987).

To determine whether social media activities have an effect on cryptocurrency price and volume, we use the following models:

1. $\Delta Y_{i t}=b_{0}+b_{1} \Delta$ negative $_{i t}+b_{2} \Delta$ positive $_{i t}+b_{4} \Delta$ sentiment $_{i t}+$

$b_{5} \Delta$ telegram ${ }_{i t}+b_{3} \Delta$ reddit ${ }_{i t}+\mathrm{b}_{5} \Delta$ twitter $_{\text {it }}+$ $\mathrm{b}_{6} \Delta$ social $_{\text {volume }_{i t}}+\varepsilon_{\text {it }}$

Where $Y_{i t}$ is the outcome variable (price and volume) of cryptocurrency ID " $i$ " at time " $\mathrm{t}$ ". The variables social_volume $i t$,

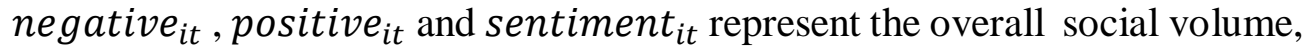
the negative social volume and the positive social volume, and the general sentiment social volume of each cryptocurrency $\mathrm{i}$ at time t. reddit ${ }_{i t}$, tele gram $_{i t}$, and twitter $_{i t}$ correspond to the social volume of each respective social network. In other words, $Y_{i t}=1$ is stationary (or more precisely covariance stationary) if its mean and variance are constant over time, and the value of the covariance between the two time periods depends only on the distance (lag) between the two time periods and not the actual time $t$ itself.

\footnotetext{
${ }^{3}$ https://developer.twitter.com/en/docs/api-reference-index.html

${ }^{4}$ https://solume.io/
} 
The first requirement simply says that the expected value of the time series should be constant and finite. If this requirement is not met, we regard data generated from this stochastic process to be from different population of processes.

Our main goal is to study the impact of the changes in social volumes on the changes in Bitcoin prices and volume. Therefore each variable is defined as a difference as follows:

$$
\Delta x=\frac{X_{t}}{X_{t-1}}-1
$$

The dependent variable of volume is defined as the difference above, yet the dependent variable of price is defined as the difference of the log price:

$$
\begin{aligned}
\text { 2. } \text { volume }_{i t} & =\frac{\text { volume }_{t}}{\text { volume }_{t-1}}-1 \\
\text { 3. } \Delta \text { price }_{i t} & =\log \frac{\left(\text { price }_{t}\right.}{\text { price } \left._{t-1}\right)}
\end{aligned}
$$

We also investigate causality between changes in social volume and cryptocurrency price/volume to determine whether social media influences market behavior or vice versa. Namely, we conduct the Granger causality test (Granger, 1980) for a time difference of no lag (model 1), 1 hour (model 2), 1 day (model 3), 3 days (model 4) and 1 week (model 5) as shown in the appendix. All Bitcoin hourly data is extracted from www.Binance.com.

\subsection{Correlation between the Different Cryptocurrencies}

To examine how the behavior of one cryptocurrency is related to the others, we conducted a correlation test on prices, as well as on volumes, see also Rothman 2018.

The results from the empirical analysis are presented as follows: Table 1.A and 1.B show the results of the panel regression from equation $1\left(\Delta Y_{i t}=\right.$ $b_{0}+b_{1} \Delta$ negative $\left._{i t} \ldots\right)$ on price and volume, respectively. These tables take into account all 16 cryptocurrencies under investigation.

Table 2.A and 2.B show the results of the correlation test on price and volume, respectively.

Tables 3.A-3.E show the separate results of the regression from equation 1 on price for models 1-5 for each cryptocurrency. Each column represents the ID number of each cryptocurrency. Similarly, tables 4.A-4.E show the separate results of the regression from equation 1 on volume for models 1-5 for each cryptocurrency.

\section{Results from the empirical analysis:}

Analysis 1 - The influence of social media: 


\section{Price}

From table 1.A column 1 we see the impact of social media on price. The coefficient for social volume is positive and significant - an increase in one unit will increase the price by 0.00505 on average. The coefficient for negative and positive social volume variables is both positive and significant: An increase of one unit in negative OR positive social volume on average increases the price of the cryptocurrencies by 0.00124 and 0.00147 , respectively.

The effect of social volume for the three different social networks is positive, yet only Reddit and Telegram social volume have a significant effect on price. As for the sentiment social volume variable, every increase of one unit on average is correlated to a significant price decrease of 0. 000098. From the separate regression, shown in table 3.1, we see that the coefficient for social volume has a different influence on each cryptocurrency. For most cryptocurrencies the coefficient is positive, with a significant effect on Bitcoin Cash, EOS, Litecoin, Ripple, and Verge. Although Bitcoin, Ethereum, Storm, Walton and ZenCash (rebranded as Horizen) experience a negative effect in relation to social volume, it is only significant for ZenCash.

Similarly, the coefficient for positive social volume is positive for most of the cryptocurrencies, with a significant effect on Dash, EOS, Storm, TRON and Verge. On the other hand, the coefficient for negative social volume is negative for most cryptocurrencies, yet only in Bitcoin is the negative influence significant.

\section{Volume}

The impact of social media on cryptocurrency volume is shown in table 1.B column 1. The coefficient for social volume is positive and significant - an increase in one unit of the social volume will increase the volume of the cryptocurrency by 0.161 on average. Similarly, the coefficients of the negative social volume and positive social volume have a positive and significant effect, with volume increase of 0.0190 and 0.0247 respectively on average.

The effect of social volume for the three different social networks is positive, yet only Reddit and Telegram have a significant affect.

In addition, the coefficient of the sentiment social volume variable is positive as well and an increase in one unit of the social volume will increase the volume of the cryptocurrency by 0.000635 on average, but the coefficient is not significant.

Same as it had on the price, the effect of social volume on the volume of the cryptocurrencies varies between the cryptocurrencies, as shown in table 4.1. For most cryptocurrencies the coefficient is positive but not significant. 
While a negative affect can be seen in Bitcoin, Cardano, EOS, Ethereum, Storm, TRON and Walton, it is only significant in Walton.

The coefficients for negative and positive social volume variables are negative for most of the cryptocurrencies, but not significant. A positive and significant effect of the negative and positive coefficients can be seen in Walton and in EOS, respectively.

\section{Analysis 2 - Causality test \\ Price}

Under the Granger Representation Theorem (Engle and Granger, 1987) we analyze the reults of the causality test on the price are presented in table 1.A. The coefficients for social volume are significant in models 1, 3, and 4 . In models 1 and 4 the affect is positive, while in model 3 the affect is negative. Similarly, the same significant influence can be seen in coefficients of negative social volume in models 1 and 3 . The coefficients of positive social volume are only significant in model 1 , with a positive influence.

The coefficients for twitter volume are positive in all the models but with no significant affect. The coefficients for Reddit volume are significant in all the models, except model 2, and have a positive effect in models 1,2 , and 5 .

The coefficients for Telegram volume also have a positive effect in most of the models, but the affect is only significant in models 1 and 3. As for the sentiment social volume variable, it has a negative effect in models 1, 3, and 5 with a significant influence only in model 1. From tables 3.A-3.E we can see the results from the different models on the price of each cryptocurrency.

Model 3 - The coefficient for Twitter social volume has the most significant effect on the prices of the cryptocurrencies. Model 5 - The coefficient for sentiment social volume and for social volume has the most significant effect on the prices of the cryptocurrencies.

\section{Volume}

Table 1.B shows the results of the causality test on volume. The coefficients for social volume are positive in models 1,4 , and 5 , yet they are only significant in model 1. Similarly, the same positive effect can be seen in coefficients of positive social volume, with a significant effect in models 1 and 5.

The coefficient of negative social volume is only significant in model 1 , with a positive influence in models 1 and 5 . The effect of social volume for the three different social networks is positive in model 1, with a significant effect for Reddit and Telegram. The positive and significant effect of Reddit 
can be seen in model 4 , yet a similar effect of Telegram can be seen in model 3.

As for the sentiment social volume variable, it has a negative effect in models 1, 3, and 5 but without significant influence.

Similarly, from tables 4.A-4.E we can see the results from the different models on the volume of each cryptocurrency.

Model 3 - The coefficient for negative social volume and for social volume has the most significant effect on the volume of the cryptocurrencies.

Model 4 - The coefficient for positive social volume and for sentiment social volume has the most significant effect on the volume of the cryptocurrencies. Model 5 - The coefficient for sentiment social volume has the most significant effect on the volume of the cryptocurrencies.

Analysis 3 - correlation: As can be seen in table 2.A, most of the prices are positively correlated with statistical significance across the different cryptocurrencies. All the cryptocurrencies, except Bitcoin and ZenCash (rebranded as Horizen), are strongly correlated in price, with a positive and significant correlation. Bitcoin is positively correlated with most of the cryptocurrencies, yet is only significantly correlated with ZenCash. ZenCash is positively and significantly correlated with Bitcoin, Bitcoin Cash, and Litecoin, but has a negative and significant correlation with Ethereum, Monero, Ripple, and Walton.

From table 2.B we can see that all the cryptocurrencies have a positive and significant correlation in their volume. Most of the correlation coefficients are over 0.5 , which means that the volume is strongly correlated between the cryptocurrencies.

\section{Tables:}

Key:

\begin{tabular}{|l|l|}
\hline Name & ID \\
\hline Bitcoin & 1 \\
\hline Bitcoin Cash & 2 \\
\hline Cardano & 3 \\
\hline Dash & 4 \\
\hline EOS & 5 \\
\hline Ethereum & 6 \\
\hline Kyber-Network & 7 \\
\hline Litecoin & 8 \\
\hline Monero & 9 \\
\hline NEO & 10 \\
\hline Ripple & 11 \\
\hline Storm & 12 \\
\hline TRON & 13 \\
\hline Verge & 14 \\
\hline Walton & 15 \\
\hline ZenCash & 16 \\
\hline (rebranded as Horizen) & \\
\hline
\end{tabular}


Table 1.B - volume

Table 1.A - price

$$
\text { Variables }
$$

negative_d

positive_d

reddit_d

telegram_d

twitter_d

sentiment_d

social_volume_d

Constant

Observations

R-squared

Number of idnum

Standard errors in parentheses

$* * * \mathrm{p}<0.01, * * \mathrm{p}<0.05, * \mathrm{p}<0.1$

16
Variables

negative_d

positive_d

reddit_d

telegram_d

$0.00406 * * *$

$(0.000849)$

4.11e-05

(0.000318)

$-9.80 \mathrm{e}-05^{*}$

$(5.57 \mathrm{e}-05)$

$0.00505^{* * * *}$

$(0.000453)$

$-0.00243 * * *$

(0.000198)

68,835

0.036

\section{Conclusion}

We believe that cryptocurrencies thrive as a result of the communities that use and support them. We take a big data approach by classifying and measuring the volume of millions of cryptocurrency related posts on online social media communities such as Twitter, Telegram and Reddit, which seem to represent a thermometer of investor behavior, on a large scale, similar to earlier studies that found that blogs can be used to evaluate public mood. In order to analze the data we use cointegration analysis. Results indicate that information about the use of social media platforms can assist in tracking real 
world behavior and may even predict real financial market trends. We find that social media mainly affects cryptocurrency volume rather than price. In fact, there is an average increase of about $16.1 \%$ in the turnover of the cryptocurrencies under investigation correlated to activity on the social media platforms we studied. This aspect may also be used for manipulations of traders through the flow of information on social networks and thus cause changes in prices. In addition, we see that social volume on Reddit and Telegram has greater impact on investor activity than Twitter. We also show that these effects vary from cryptocurrency to cryptocurrency. For example, for Ripple, there is a very significant price correlation with negative sentiment on Twitter while for EOS there is significant price correlation with positive sentiment on Twitter (Table 3A).

The study also shows that all cryptocurrencies under investigation are highly correlated in price except for Bitcoin and ZenCash (rebranded as Horizen) which are only correlated to one another. In other words, investing in both the Bitcoin and ZenCash pair as well as the other cryptocurrencies can give broad exposure to the world of crypto. Because ZenCash is the only cryptocurrency that behaves in a similar way to Bitcoin, its acquisition can be a much cheaper method of exposure to Bitcoin. We show that activity on social media has a true causal relationship with cryptocurrency volume/price fluctuations and not the other way around. However, social media is developing on an exponential scale and exploring Reddit in 2019 may not be relevant in 2020, thus an on-going analysis is needed. In addition, other parameters can impact cryptocurrency trading such as investors' trust and/or regulation which are not captured in this study.

This research contributes to the growing literature on cryptocurrency and investor activity around it. The 'new world' of innovative social media platforms may play a crucial part in the future of trading platforms. Our research may also be useful for investors in a better understanding the connection between social media and cryptocurrencies. Specically, understanding which cryptocurrency is more affected and when by social media platforms.

\section{References:}

1. Bollen, J., Mao, H., \& Pepe, A. (2011). Modeling public mood and emotion: Twitter sentiment and socio-economic phenomena. Icwsm, 11, 450-453.

2. Dyhrberg, A. H. (2016). Hedging capabilities of bitcoin. Is it the virtual gold?. Finance Research Letters, 16, 139-144.

3. Engle, R. F., \& Granger, C. W. (1987). Co-integration and error correction: representation, estimation, and testing. Econometrica: journal of the Econometric Society, 251-276. 
4. Go, A., Bhayani, R., \& Huang, L. (2009). Twitter sentiment classification using distant supervision. CS224N Project Report, Stanford, 1(12).

5. Granger, C. W. (1980). Testing for causality: a personal viewpoint. Journal of Economic Dynamics and control, 2, 329-352.

6. Kim, J. H. (2009b). Automatic variance ratio test under conditional heteroscedasticity. Finance Research Letters, 3, 179-185.

7. Mai, E., \& Hranac, R. (2013). Twitter interactions as a data source for transportation incidents. In Proc. Transportation Research Board 92nd Ann. Meeting (No. 13-1636).

8. Mai, F., Shan, Z., Bai, Q., Wang, X., \& Chiang, R. H. (2018). How does social media impact Bitcoin value? A test of the silent majority hypothesis. Journal of Management Information Systems, 35(1), 1952.

9. Nelson, C. R., and Plosser, C. R. (1982). Trends and random walks in macroeconmic time series: some evidence and implications. Journal of monetary economics, 10(2), 139-162.

10. Rao, T., \& Srivastava, S. (2012, August). Analyzing stock market movements using twitter sentiment analysis. In Proceedings of the 2012 international conference on advances in social networks analysis and mining (ASONAM 2012) (pp. 119-123). IEEE Computer Society.

11. Selgin, G. (2015). Synthetic commodity money. Journal of Financial Stability, 17, 92-99.

12. S. Ye and F. Wu. Estimating the size of online social networks. In Proc. of the IEEE 2nd Intl. Conf. on Social Computing, pages 169176, Aug. 2010

13. Rothman, T. (2018). Digital Coins Eco-System: Analyzing the Network of Prices and Volume. Journal of Finance and Economics, 6(6), 250-253.

14. Thelwall, M. (2017). The Heart and soul of the web? Sentiment strength detection in the social web with SentiStrength. In Cyberemotions (pp. 119-134). Springer, Cham.

15. Thelwall, M., \& Buckley, K. (2013). Topic-based sentiment analysis for the social web: The role of mood and issue-related words. Journal of the American Society for Information Science and Technology, 64(8), 1608-1617. 


\section{Appendix}

Table 2.A - correlation of price

\begin{tabular}{|c|c|c|c|c|c|c|c|c|c|c|c|c|c|c|c|c|}
\hline Price & 1 & 2 & 3 & 4 & 5 & 6 & 7 & 8 & 9 & 10 & 11 & 12 & 13 & 14 & 15 & 16 \\
\hline 1 & 1 & & & & & & & & & & & & & & & \\
\hline 2 & 0.0418 & 1 & & & & & & & & & & & & & & \\
\hline 3 & 0.0408 & $0.891 * * *$ & 1 & & & & & & & & & & & & & \\
\hline 4 & -0.0054 & $0.801 * * *$ & $0.860 * * *$ & 1 & & & & & & & & & & & & \\
\hline 5 & 0.0427 & $0.862^{* * *}$ & $0.793^{* * *}$ & $0.754 * * *$ & 1 & & & & & & & & & & & \\
\hline 6 & 0.00319 & $0.755^{* * * *}$ & $0.732^{* * * *}$ & $0.836^{* * * *}$ & $0.845^{* * * *}$ & 1 & & & & & & & & & & \\
\hline 7 & -0.0101 & $0.843^{* * *}$ & $0.894 * * *$ & $0.913^{* * *}$ & $0.807 * * *$ & $0.840^{* * *}$ & 1 & & & & & & & & & \\
\hline 8 & 0.0166 & $0.915^{* * *}$ & $0.863^{* * *}$ & $0.839 * * *$ & $0.912 * * *$ & $0.883^{* * *}$ & $0.887 * * *$ & 1 & & & & & & & & \\
\hline 9 & 0.0116 & $0.650^{* * *}$ & $0.754 * * *$ & $0.865^{* * *}$ & $0.642 * * *$ & $0.774 * * *$ & $0.813^{* * *}$ & $0.692 * * *$ & 1 & & & & & & & \\
\hline 10 & 0.00833 & $0.828^{* * *}$ & $0.881 * * *$ & $0.889 * * *$ & $0.848 * * *$ & $0.877 * * *$ & $0.942 * * *$ & $0.907 * * *$ & $0.799 * * *$ & 1 & & & & & & \\
\hline 11 & -0.0095 & $0.856^{* * *}$ & $0.804 * * *$ & $0.837 * * *$ & $0.918 * * *$ & $0.914 * * *$ & $0.852 * * *$ & $0.932 * * *$ & $0.729 * * *$ & $0.878 * * *$ & 1 & & & & & \\
\hline 12 & 0.0106 & $0.870^{* * *}$ & $0.925^{* * *}$ & $0.920 * * *$ & $0.829 * * *$ & $0.843^{* * *}$ & $0.959 * * *$ & $0.902 * * *$ & $0.830 * * *$ & $0.954 * * *$ & $0.872 * * *$ & 1 & & & & \\
\hline 13 & 0.0331 & $0.914 * * *$ & $0.897 * * *$ & $0.858 * * *$ & $0.925^{* * *}$ & $0.866^{* * *}$ & $0.901 * * *$ & $0.949 * * *$ & $0.744 * * *$ & $0.918^{* * *}$ & $0.934 * * *$ & $0.927 * * *$ & 1 & & & \\
\hline 14 & 0.0195 & $0.870^{* * *}$ & $0.934 * * *$ & $0.891 * * *$ & $0.729^{* * *}$ & $0.719^{* * *}$ & $0.923^{* * *}$ & $0.832 * * *$ & $0.800^{* * *}$ & $0.881 * * *$ & $0.773^{* * *}$ & $0.942 * * *$ & $0.869^{* * *}$ & 1 & & \\
\hline 15 & 0.00528 & $0.772 * * *$ & $0.750^{* * *}$ & $0.841^{* * *}$ & $0.858^{* * *}$ & $0.928 * * *$ & $0.865^{* * *}$ & $0.893^{* * *}$ & $0.748^{* * *}$ & $0.895 * * *$ & $0.923 * * *$ & $0.876^{* * *}$ & $0.888^{* * *}$ & $0.758^{* * *}$ & 1 & \\
\hline 16 & $0.0629^{*}$ & $\begin{array}{l}0.0903 * * \\
*\end{array}$ & 0.0317 & $-0.166^{* * *}$ & 0.0237 & $-0.147 * * *$ & -0.026 & $0.0524 *$ & $-0.302 * * *$ & -0.006 & $-0.100^{* * *}$ & -0.035 & -0.0035 & -0.017 & $-0.123 * * *$ & 1 \\
\hline
\end{tabular}

$* \mathrm{p}<0.05, * * \mathrm{p}<0.01, * * * \mathrm{p}<0.001$ 
Table 2.B - correlation of volume

\begin{tabular}{|c|c|c|c|c|c|c|c|c|c|c|c|c|c|c|c|c|}
\hline Volume & 1 & 2 & 3 & 4 & 5 & 6 & 7 & 8 & 9 & 10 & 11 & 12 & 13 & 14 & 15 & 16 \\
\hline 1 & 1 & & & & & & & & & & & & & & & \\
\hline 2 & $0.849 * * *$ & 1 & & & & & & & & & & & & & & \\
\hline 3 & $0.310 * * *$ & $0.674 * * *$ & 1 & & & & & & & & & & & & & \\
\hline 4 & $0.944 * * *$ & $0.949 * * *$ & $0.415^{* * * *}$ & 1 & & & & & & & & & & & & \\
\hline 5 & $0.911^{* * *}$ & $0.991 * * *$ & $0.620 * * *$ & $0.969 * * *$ & 1 & & & & & & & & & & & \\
\hline 6 & $0.852 * * *$ & $0.880^{* * * *}$ & $0.730 * * *$ & $0.811^{* * *}$ & $0.911^{* * *}$ & 1 & & & & & & & & & & \\
\hline 7 & $0.861 * * *$ & $0.990 * * *$ & $0.576^{* * *}$ & $0.973 * * *$ & $0.982 * * *$ & $0.821^{* * *}$ & 1 & & & & & & & & & \\
\hline 8 & $0.875^{* * *}$ & $0.998 * * *$ & $0.657 * * *$ & $0.958 * * *$ & $0.997 * * *$ & $0.897 * * *$ & $0.988 * * *$ & 1 & & & & & & & & \\
\hline 9 & $0.910 * * *$ & $0.977 * * *$ & $0.503 * * *$ & $0.993 * * *$ & $0.984 * * *$ & $0.826^{* * *}$ & $0.993 * * *$ & $0.981 * * *$ & 1 & & & & & & & \\
\hline 10 & $0.234 * * *$ & $0.630^{* * * *}$ & $0.996^{* * * *}$ & $0.357 * * *$ & $0.566^{* * * *}$ & $0.668 * * *$ & $0.532 * * *$ & $0.610^{* * * *}$ & $0.452 * * *$ & 1 & & & & & & \\
\hline 11 & $0.826^{* * *}$ & $0.987 * * *$ & $0.763 * * *$ & $0.904 * * *$ & $0.980 * * *$ & $0.931 * * *$ & $0.956 * * *$ & $0.988 * * *$ & $0.938 * * *$ & $0.718 * * *$ & 1 & & & & & \\
\hline 12 & $0.187 * * *$ & $0.583^{* * * *}$ & $0.992 * * *$ & $0.302 * * *$ & $0.519 * * *$ & $0.641^{* * * *}$ & $0.479 * * *$ & $0.562 * * *$ & $0.398 * * *$ & $0.998 * * *$ & $0.677 * * *$ & 1 & & & & \\
\hline 13 & $0.424 * * *$ & $0.717 * * *$ & $0.987 * * *$ & $0.484 * * *$ & $0.683^{* * *}$ & $0.821 * * *$ & $0.617 * * *$ & $0.709 * * *$ & $0.559 * * *$ & $0.969 * * *$ & $0.811^{* * * *}$ & $0.964 * * *$ & 1 & & & \\
\hline 14 & $0.403 * * *$ & $0.703 * * *$ & $0.989 * * *$ & $0.465^{* * *}$ & $0.667 * * *$ & $0.808 * * *$ & $0.601 * * *$ & $0.694 * * *$ & $0.542 * * *$ & $0.974 * * *$ & $0.798 * * *$ & $0.969 * * *$ & $1.000 * * *$ & 1 & & \\
\hline 15 & $0.686^{* * *}$ & $0.961 * * *$ & $0.836^{* * * *}$ & $0.827 * * *$ & $0.924 * * *$ & $0.847 * * *$ & $0.927 * * *$ & $0.949 * * *$ & $0.885^{* * * *}$ & $0.810^{* * *}$ & $0.974 * * *$ & $0.772 * * *$ & $0.848 * * *$ & $0.839 * * *$ & 1 & \\
\hline 16 & $0.672 * * *$ & $0.942 * * *$ & $0.863^{* * * *}$ & $0.797 * * *$ & $0.908 * * *$ & $0.865^{* * * *}$ & $0.898 * * *$ & $0.932 * * *$ & $0.855^{* * * *}$ & $0.835^{* * * *}$ & $0.967 * * *$ & $0.801 * * *$ & $0.879 * * *$ & $0.871 * * *$ & $0.989 * * *$ & 1 \\
\hline
\end{tabular}


Linear regression by cryptocurrency ID and models:

\begin{tabular}{|c|c|c|c|c|c|c|c|c|c|c|c|c|c|c|c|c|}
\hline 16 & 15 & 14 & 13 & 12 & 11 & 10 & 9 & 8 & 7 & 6 & 5 & 4 & 3 & 2 & 1 & \\
\hline- & - & 0.0044 & 0.00093 & - & 0.0012 & - & 0.000 & - & 0.0001 & - & - & 0.0018 & - & 0.0006 & - & negati \\
\hline 0.0006 & 0.0006 & $3 * * *$ & 7 & 0.0005 & $0 * *$ & 0.001 & 283 & 0.0002 & 10 & 0.0003 & 0.0000 & 4 & 0.0001 & 93 & 0.00094 & ve_d \\
\hline 61 & 78 & & & 94 & & 08 & & 78 & & 32 & 571 & & 76 & & $3 * *$ & \\
\hline$(-0.40)$ & $(-0.44)$ & (5.11) & (1.51) & $(-0.28)$ & (3.18) & $\begin{array}{l}(- \\
1.39)\end{array}$ & (1.05) & $(-1.10)$ & $(0.05)$ & $(-0.91)$ & $(-0.08)$ & (1.89) & $(-0.19)$ & (1.88) & $(-2.63)$ & \\
\hline 0.0006 & 0.0007 & 0.0040 & 0.00172 & 0.0036 & - & 0.000 & 0.000 & - & 0.0007 & - & 0.0030 & 0.0016 & - & - & 0.00097 & positi \\
\hline 45 & 08 & $4 * * *$ & $* *$ & $1 * *$ & $\begin{array}{l}0.0003 \\
62\end{array}$ & 852 & 382 & $\begin{array}{l}0.0002 \\
97\end{array}$ & 77 & $\begin{array}{l}0.0022 \\
1\end{array}$ & $9 * * *$ & $3^{*}$ & $\begin{array}{l}0.0000 \\
784\end{array}$ & $\begin{array}{l}0.0000 \\
435\end{array}$ & 4 & ve_d \\
\hline$(0.53)$ & $(0.59)$ & $(5.27)$ & $(2.76)$ & $(2.85)$ & $(-0.82)$ & $(1.52)$ & (1.60) & $(-1.20)$ & $(0.67)$ & $(-1.58)$ & (4.54) & $(2.41)$ & $(-0.12)$ & $(-0.12)$ & (1.39) & \\
\hline 0.0013 & - & 0.0076 & 0.00295 & 0.0018 & 0.0157 & 0.003 & 0.002 & 0.0066 & - & 0.0067 & 0.0020 & - & 0.0071 & 0.0047 & 0.00093 & reddit \\
\hline 0 & $\begin{array}{l}0.0002 \\
20\end{array}$ & 0 *** & $* * *$ & 3 & $* * *$ & $86^{* * *}$ & $13^{*}$ & $7 * * *$ & $\begin{array}{l}0.0022 \\
8\end{array}$ & $8 * * *$ & $1^{*}$ & $\begin{array}{l}0.0040 \\
6\end{array}$ & $6 * * *$ & 1 & 8 & _d \\
\hline$(0.96)$ & $(-0.25)$ & (10.41) & $(5.01)$ & $(0.17)$ & (13.08) & $(5.44)$ & (2.33) & (14.65) & $(-1.28)$ & (3.68) & $(2.01)$ & $(-1.15)$ & (10.05) & (1.77) & $(0.87)$ & \\
\hline- & 0.0005 & 0.0007 & 0.00000 & 0.0211 & 0.0002 & 0.000 & 0.000 & 0.0001 & - & 0.0088 & 0.0011 & 0.0001 & 0.0003 & 0.0010 & 0.00031 & telegr \\
\hline $\begin{array}{c}0.0007 \\
02\end{array}$ & 58 & $71^{* *}$ & 421 & $* *$ & 79 & 567 & 107 & 59 & $\begin{array}{c}0.0008 \\
92\end{array}$ & $5 * * *$ & $2^{*}$ & 12 & 41 & $1 * * *$ & 3 & am_d \\
\hline$(-0.50)$ & $(0.62)$ & $(2.71)$ & $(0.11)$ & $(2.76)$ & $(1.27)$ & $(1.29)$ & $(0.64)$ & $(1.52)$ & $(-0.63)$ & (9.63) & $(2.15)$ & $(0.01)$ & $(0.78)$ & $(5.38)$ & $(0.94)$ & \\
\hline
\end{tabular}




\begin{tabular}{|c|c|c|c|c|c|c|c|c|c|c|c|c|c|c|c|c|}
\hline 0.0033 & 0.0001 & - & 0.00938 & 0.0039 & - & 0.003 & - & 0.0013 & 0.0001 & 0.0282 & - & - & - & 0.0003 & 0.00151 & twitte \\
\hline 5 & 21 & $\begin{array}{c}0.0041 \\
0\end{array}$ & $* * *$ & 1 & $\begin{array}{c}0.0024 \\
8\end{array}$ & $04 * *$ & $\begin{array}{c}0.000 \\
721\end{array}$ & 0 & 45 & $* * *$ & $\begin{array}{c}0.0032 \\
9 * *\end{array}$ & $\begin{array}{c}0.0055 \\
3\end{array}$ & $\begin{array}{c}0.0007 \\
66\end{array}$ & 38 & & r_d \\
\hline$(1.92)$ & $(0.09)$ & $(-1.66)$ & (3.72) & $(0.19)$ & $(-1.86)$ & (2.90) & $\begin{array}{l}(- \\
1.76)\end{array}$ & (1.54) & $(0.03)$ & $(9.56)$ & $(-2.73)$ & $(-0.49)$ & $(-0.73)$ & $(0.38)$ & (1.04) & \\
\hline- & 0.0000 & - & - & 0.0001 & - & 0.000 & 0.000 & - & 0.0000 & - & - & - & - & - & - & senti \\
\hline $\begin{array}{c}0.0008 \\
52 *\end{array}$ & 107 & $\begin{array}{l}0.0002 \\
63\end{array}$ & $\begin{array}{l}0.00010 \\
3\end{array}$ & 81 & $\begin{array}{l}0.0001 \\
56\end{array}$ & 0952 & 0862 & $\begin{array}{l}0.0003 \\
60 * *\end{array}$ & 382 & $\begin{array}{l}0.0000 \\
208\end{array}$ & $\begin{array}{l}0.0004 \\
63^{*}\end{array}$ & $\begin{array}{c}0.0000 \\
0570\end{array}$ & $\begin{array}{c}0.0000 \\
382\end{array}$ & $\begin{array}{c}0.0000 \\
228\end{array}$ & $\begin{array}{c}0.00003 \\
20\end{array}$ & $\begin{array}{l}\text { ment_ } \\
\mathrm{d}\end{array}$ \\
\hline$(-2.01)$ & $(0.04)$ & $(-0.89)$ & $(-0.44)$ & $(0.29)$ & $(-0.81)$ & $(0.50)$ & (1.01) & $(-3.00)$ & $(0.09)$ & $(-0.08)$ & $(-2.14)$ & $(-0.03)$ & $(-0.17)$ & $(-0.17)$ & $(-0.37)$ & \\
\hline- & - & 0.0179 & 0.00542 & - & 0.0274 & 0.001 & 0.001 & 0.0068 & 0.0035 & - & 0.0146 & 0.0053 & 0.0012 & 0.0152 & -0.00233 & social \\
\hline $\begin{array}{c}0.0041 \\
4^{*}\end{array}$ & $\begin{array}{c}0.0003 \\
39\end{array}$ & $* * *$ & & $\begin{array}{c}0.0026 \\
1\end{array}$ & $* * *$ & 94 & 95 & $5 * * *$ & 9 & $\begin{array}{c}0.0028 \\
0\end{array}$ & $* * *$ & 8 & 6 & $* * *$ & & $\begin{array}{l}\text { _volu } \\
\text { me_d }\end{array}$ \\
\hline$(-2.08)$ & $(-0.21)$ & $(6.27)$ & (1.54) & $(-0.13)$ & $(9.69)$ & $(0.81)$ & $(1.20)$ & $(4.61)$ & $(0.73)$ & $(-0.66)$ & $(5.83)$ & $(0.48)$ & $(0.52)$ & (4.12) & $(-1.15)$ & \\
\hline- & - & - & - & 0.0015 & - & - & - & - & - & - & - & - & - & - & - & _cons \\
\hline 0.0016 & 0.0007 & 0.0075 & 0.00348 & 4 & 0.0035 & 0.002 & 0.000 & 0.0015 & 0.0032 & 0.0014 & 0.0027 & 0.0009 & 0.0025 & 0.0019 & 0.00006 & \\
\hline 5 & 66 & $3 * * *$ & $* * *$ & & $5 * * *$ & $02 *$ & 421 & $5 * * *$ & $1^{*}$ & $7 * *$ & $3 * *$ & 94 & $6^{* *}$ & $2 * *$ & 74 & \\
\hline$(-1.15)$ & $(-0.54)$ & $(-6.81)$ & $(-4.08)$ & $(0.90)$ & $(-5.97)$ & $\begin{array}{c}(- \\
2.49)\end{array}$ & $\begin{array}{c}(- \\
1.08)\end{array}$ & $(-4.17)$ & $(-2.17)$ & $(-2.94)$ & $(-2.89)$ & $(-1.40)$ & $(-2.61)$ & $(-3.18)$ & $(-0.38)$ & \\
\hline 424 & 2577 & 5345 & 5709 & 934 & 6101 & 5529 & 5054 & 6009 & 1704 & 6119 & 5176 & 1727 & 4490 & 5976 & 5961 & $\mathrm{~N}$ \\
\hline
\end{tabular}


Table 3B - model 2 - price

\begin{tabular}{|c|c|c|c|c|c|c|c|c|c|c|c|c|c|c|c|c|}
\hline 16 & 15 & 14 & 13 & 12 & 11 & 10 & 9 & 8 & 7 & 6 & 5 & 4 & 3 & 2 & 1 & \\
\hline 0.0016 & - & - & - & 0.002 & - & 0.0003 & - & 0.0003 & 0.00030 & - & 0.0005 & 0.0008 & 0.00101 & - & - & negativ \\
\hline 1 & $\begin{array}{c}0.0004 \\
58\end{array}$ & $\begin{array}{c}0.0005 \\
99\end{array}$ & $\begin{array}{c}0.0007 \\
54\end{array}$ & 86 & $\begin{array}{c}0.0008 \\
31\end{array}$ & 56 & $\begin{array}{c}0.0000 \\
858\end{array}$ & 90 & 4 & $\begin{array}{c}0.0002 \\
17\end{array}$ & 72 & 47 & & $\begin{array}{c}0.0002 \\
21\end{array}$ & $\begin{array}{c}0.00001 \\
42\end{array}$ & e_d \\
\hline$(0.73)$ & $(-0.24)$ & $(-0.66)$ & $(-1.20)$ & $(1.27)$ & $(-1.87)$ & $(0.45)$ & $(-0.30)$ & $(1.46)$ & $(0.13)$ & $(-0.58)$ & $(0.79)$ & $(0.85)$ & (1.16) & $(-0.61)$ & $(-0.04)$ & \\
\hline - & 0.0019 & - & - & 0.001 & 0.0006 & - & 0.0000 & - & - & 0.0012 & - & - & 0.00044 & 0.0002 & 0.00033 & positiv \\
\hline $\begin{array}{c}0.0020 \\
1\end{array}$ & 9 & $\begin{array}{c}0.0002 \\
03\end{array}$ & $\begin{array}{c}0.0000 \\
676\end{array}$ & 64 & 43 & $\begin{array}{c}0.0003 \\
86\end{array}$ & 792 & $\begin{array}{c}0.0000 \\
0637\end{array}$ & $\begin{array}{c}0.00091 \\
0\end{array}$ & 8 & $\begin{array}{c}0.0002 \\
92\end{array}$ & $\begin{array}{c}0.0002 \\
70\end{array}$ & 7 & 60 & 9 & e_d \\
\hline$(-1.25)$ & $(1.36)$ & $(-0.25)$ & $(-0.11)$ & $(1.23)$ & $(1.24)$ & $(-0.68)$ & $(0.32)$ & $(-0.02)$ & $(-0.68)$ & $(0.89)$ & $(-0.44)$ & $(-0.39)$ & $(0.70)$ & $(0.73)$ & $(0.48)$ & \\
\hline - & - & 0.0003 & 0.0008 & 0.000 & 0.0015 & 0.0003 & - & 0.0001 & 0.00171 & 0.0013 & 0.0008 & - & 0.00058 & 0.0025 & 0.00011 & reddit_ \\
\hline $\begin{array}{c}0.0014 \\
9\end{array}$ & $\begin{array}{c}0.0024 \\
0^{*}\end{array}$ & 37 & 02 & 0310 & 0 & 38 & $\begin{array}{c}0.0009 \\
33\end{array}$ & 08 & & 4 & 15 & $\begin{array}{c}0.0007 \\
96\end{array}$ & 3 & 8 & 8 & d \\
\hline$(-0.83)$ & $(-2.19)$ & $(0.44)$ & (1.34) & $(0.00)$ & $(1.06)$ & $(0.47)$ & $(-0.97)$ & $(0.22)$ & $(0.83)$ & $(0.71)$ & $(0.83)$ & $(-0.22)$ & $(0.87)$ & $(0.99)$ & $(0.11)$ & \\
\hline $\begin{array}{c}0.0008 \\
45\end{array}$ & $\begin{array}{c}0.0016 \\
9\end{array}$ & $\begin{array}{c}0.0004 \\
34\end{array}$ & $\begin{array}{c}0.0000 \\
111\end{array}$ & $\begin{array}{c}- \\
0.016 \\
9^{*}\end{array}$ & $\begin{array}{c}- \\
0.0001 \\
40\end{array}$ & $\begin{array}{c}0.0006 \\
03\end{array}$ & $\begin{array}{c}- \\
0.0000 \\
0215\end{array}$ & $\begin{array}{c}- \\
0.0000 \\
0102\end{array}$ & 0.00271 & $\begin{array}{c}- \\
0.0009 \\
69\end{array}$ & $\begin{array}{c}- \\
0.0004 \\
99\end{array}$ & $\begin{array}{c}- \\
0.0043 \\
4\end{array}$ & $\begin{array}{c}0.00097 \\
7 *\end{array}$ & $\begin{array}{c}- \\
0.0001 \\
03\end{array}$ & $\begin{array}{c}- \\
0.00014 \\
5\end{array}$ & $\begin{array}{l}\text { telegra } \\
\mathrm{m} \_\mathrm{d}\end{array}$ \\
\hline$(0.45)$ & $(1.53)$ & $(1.46)$ & $(0.29)$ & 2.12) & $(-0.54)$ & $(1.35)$ & $(-0.01)$ & $(-0.01)$ & (1.65) & $(-1.03)$ & $(-0.97)$ & $(-0.37)$ & $(2.38)$ & $(-0.56)$ & $(-0.43)$ & \\
\hline- & - & 0.0018 & - & 0.002 & 0.0015 & 0.0009 & - & - & 0.00295 & 0.0035 & 0.0015 & 0.0029 & 0.00028 & 0.0002 & - & twitter_ \\
\hline $\begin{array}{c}0.0006 \\
29\end{array}$ & $\begin{array}{c}0.0044 \\
1 * *\end{array}$ & 9 & $\begin{array}{c}0.0009 \\
62\end{array}$ & 82 & 1 & 08 & $\begin{array}{c}0.0001 \\
06\end{array}$ & $\begin{array}{c}0.0002 \\
11\end{array}$ & & 8 & 0 & 2 & 2 & 07 & $\begin{array}{c}0.00024 \\
5\end{array}$ & $\mathrm{~d}$ \\
\hline$(-0.27)$ & $(-2.60)$ & $(0.73)$ & $(-0.38)$ & $(0.13)$ & $(0.97)$ & $(0.86)$ & $(-0.25)$ & $(-0.24)$ & $(0.55)$ & $(1.18)$ & $(1.26)$ & $(0.25)$ & $(0.28)$ & $(0.24)$ & $(-0.17)$ & \\
\hline 0.0000 & 0.0000 & 0.0000 & - & - & - & - & - & 0.0000 & 0.00023 & 0.0000 & 0.0002 & - & 0.00005 & 0.0002 & - & sentime \\
\hline
\end{tabular}




\begin{tabular}{|c|c|c|c|c|c|c|c|c|c|c|c|c|c|c|c|c|}
\hline $\begin{array}{c}679 \\
(0.12)\end{array}$ & $(0.29)$ & $(0.13)$ & $\begin{array}{c}0.0001 \\
51 \\
(-0.63)\end{array}$ & $\begin{array}{c}0.000 \\
0725 \\
(- \\
0.11)\end{array}$ & $\begin{array}{c}0.0000 \\
932 \\
(-0.41)\end{array}$ & $\begin{array}{c}0.0000 \\
328 \\
(-0.17)\end{array}$ & $\begin{array}{c}0.0000 \\
195 \\
(-0.22)\end{array}$ & $\begin{array}{c}127 \\
(0.10)\end{array}$ & $(0.48)$ & $\begin{array}{c}632 \\
(0.24)\end{array}$ & $\begin{array}{c}79 \\
(1.31)\end{array}$ & $\begin{array}{c}0.0000 \\
461 \\
(-0.21)\end{array}$ & $\begin{array}{c}83 \\
(0.27)\end{array}$ & $\begin{array}{c}53 \\
(1.89)\end{array}$ & $\begin{array}{c}0.00002 \\
96 \\
(-0.34)\end{array}$ & nt_d \\
\hline $\begin{array}{c}0.0024 \\
1 \\
(0.91)\end{array}$ & $\begin{array}{c}0.0026 \\
5 \\
(1.33)\end{array}$ & $\begin{array}{c}- \\
0.0019 \\
6 \\
(-0.66)\end{array}$ & $\begin{array}{c}0.0018 \\
6 \\
(0.52)\end{array}$ & $\begin{array}{c}- \\
0.001 \\
98 \\
(- \\
0.09)\end{array}$ & $\begin{array}{c}- \\
0.0040 \\
7 \\
(-1.23)\end{array}$ & $\begin{array}{c}- \\
0.0030 \\
2 \\
(-1.25)\end{array}$ & $\begin{array}{c}0.0016 \\
4 \\
(0.96)\end{array}$ & $\begin{array}{c}- \\
0.0014 \\
2 \\
(-0.90)\end{array}$ & $\begin{array}{c}- \\
0.00365 \\
(-0.64)\end{array}$ & $\begin{array}{c}- \\
0.0037 \\
5 \\
(-0.86)\end{array}$ & $\begin{array}{c}- \\
0.0030 \\
1 \\
(-1.22)\end{array}$ & $\begin{array}{c}- \\
0.0022 \\
3 \\
(-0.19)\end{array}$ & -0.00153 & $\begin{array}{c}- \\
0.0008 \\
46 \\
(-0.23)\end{array}$ & $\begin{array}{c}- \\
0.00010 \\
5 \\
(-0.05)\end{array}$ & $\begin{array}{l}\text { social_ } \\
\text { volume } \\
\text { _d }\end{array}$ \\
\hline $\begin{array}{c}- \\
0.0007 \\
38 \\
(-0.39)\end{array}$ & $\begin{array}{c}- \\
0.0026 \\
8 \\
(-1.55)\end{array}$ & $\begin{array}{c}- \\
0.0004 \\
32 \\
(-0.37)\end{array}$ & $\begin{array}{c}0.0003 \\
06 \\
(0.35)\end{array}$ & $\begin{array}{c}- \\
0.002 \\
92 \\
(- \\
1.64) \\
\end{array}$ & $\begin{array}{c}0.0002 \\
08 \\
(0.30)\end{array}$ & $\begin{array}{c}- \\
0.0002 \\
88 \\
(-0.35)\end{array}$ & $\begin{array}{c}- \\
0.0002 \\
15 \\
(-0.52)\end{array}$ & $\begin{array}{c}- \\
0.0000 \\
193 \\
(-0.05)\end{array}$ & $\begin{array}{c}- \\
0.00591 \\
* * * \\
(-3.44)\end{array}$ & $\begin{array}{c}0.0000 \\
330 \\
(0.06)\end{array}$ & $\begin{array}{c}- \\
0.0004 \\
51 \\
(-0.48)\end{array}$ & $\begin{array}{c}- \\
0.0024 \\
9 * * * \\
(-3.41)\end{array}$ & -0.00153 & $\begin{array}{c}- \\
0.0004 \\
82 \\
(-0.81)\end{array}$ & $\begin{array}{c}- \\
0.00007 \\
18 \\
(-0.40)\end{array}$ & _cons \\
\hline 424 & 2577 & 5344 & $\begin{array}{l}5708 \\
\end{array}$ & 933 & 6100 & $\begin{array}{l}5528 \\
\end{array}$ & 5053 & 6008 & 1704 & 6118 & 5175 & 1726 & 4490 & 5975 & 5960 & $\mathrm{~N}$ \\
\hline
\end{tabular}

Table 3C - model 3 - price

\begin{tabular}{|c|c|c|c|c|c|c|c|c|c|c|c|c|c|c|c|c|}
\hline 16 & 15 & 14 & 13 & 12 & 11 & 10 & 9 & 8 & 7 & 6 & 5 & 4 & 3 & 2 & 1 & \\
\hline $\begin{array}{c}- \\
0.00055 \\
6\end{array}$ & -0.00243 & $\begin{array}{c}- \\
0.00218 \\
*\end{array}$ & $\begin{array}{c}- \\
0.00258 \\
* * *\end{array}$ & 0.00247 & $\begin{array}{c}0.00027 \\
5\end{array}$ & -0.00101 & $\begin{array}{c}- \\
0.00029 \\
8\end{array}$ & $\begin{array}{c}0.00041 \\
7\end{array}$ & $\begin{array}{c}0.0002 \\
63\end{array}$ & $\begin{array}{c}0.00067 \\
2\end{array}$ & $\begin{array}{c}0.00016 \\
6\end{array}$ & $\begin{array}{c}- \\
0.00126\end{array}$ & $\begin{array}{c}- \\
0.00046 \\
4\end{array}$ & $\begin{array}{c}- \\
0.00054 \\
8\end{array}$ & $\begin{array}{c}0.00005 \\
61\end{array}$ & negative_d \\
\hline$(-0.43)$ & $(-1.20)$ & $(-2.51)$ & $(-4.19)$ & (1.53) & $(0.63)$ & $(-1.30)$ & $(-1.08)$ & (1.54) & $(0.14)$ & (1.82) & $(0.23)$ & $(-1.09)$ & $(-0.53)$ & $(-1.47)$ & $(0.15)$ & \\
\hline $\begin{array}{c}- \\
0.00364 \\
* * *\end{array}$ & 0.000511 & $\begin{array}{c}0.00040 \\
9\end{array}$ & $\begin{array}{c}- \\
0.00080 \\
8\end{array}$ & $\begin{array}{c}- \\
0.00000 \\
941\end{array}$ & $\begin{array}{c}0.00007 \\
35\end{array}$ & $\begin{array}{c}0.00014 \\
6\end{array}$ & $\begin{array}{c}- \\
0.00012 \\
7\end{array}$ & $\begin{array}{c}0.00003 \\
87\end{array}$ & $\begin{array}{c}0.0005 \\
58\end{array}$ & $\begin{array}{c}0.00544 \\
* * *\end{array}$ & $\begin{array}{c}- \\
0.00028 \\
4\end{array}$ & $\begin{array}{c}- \\
0.00180 \\
*\end{array}$ & $\begin{array}{c}0.00157 \\
*\end{array}$ & $\begin{array}{c}0.00019 \\
2\end{array}$ & $\begin{array}{c}- \\
0.00017 \\
5\end{array}$ & positive_d \\
\hline$(-3.81)$ & (0.32) & $(0.53)$ & $(-1.31)$ & $(-0.01)$ & $(0.15)$ & $(0.26)$ & $(-0.52)$ & $(0.15)$ & $(0.54)$ & $(3.85)$ & $(-0.42)$ & $(-2.24)$ & $(2.43)$ & $(0.53)$ & $(-0.25)$ & \\
\hline
\end{tabular}




\begin{tabular}{|c|c|c|c|c|c|c|c|c|c|c|c|c|c|c|c|c|}
\hline $\begin{array}{c}- \\
0.00064 \\
9\end{array}$ & $\begin{array}{c}- \\
0.000202\end{array}$ & $\begin{array}{c}- \\
0.00297 \\
* * *\end{array}$ & $\begin{array}{c}- \\
0.00454 \\
* * *\end{array}$ & 0.00473 & 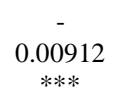 & $\begin{array}{c}0.00427 \\
* * *\end{array}$ & $\begin{array}{c}0.00077 \\
6\end{array}$ & $\begin{array}{c}0.00106 \\
*\end{array}$ & $\begin{array}{c}0.0004 \\
13\end{array}$ & $\begin{array}{c}0.0204 * \\
* *\end{array}$ & $\begin{array}{c}0.00324 \\
* *\end{array}$ & 0.00142 & $\underset{* *}{-}$ & $\stackrel{-}{-}$ & $\begin{array}{c}0.00082 \\
1\end{array}$ & reddit_d \\
\hline$(-0.61)$ & $(-0.17)$ & $(-4.06)$ & $(-7.75)$ & $(0.59)$ & $(-6.58)$ & $(6.10)$ & $(0.83)$ & $(2.18)$ & $(0.26)$ & $(10.96)$ & (3.28) & $(0.34)$ & $(-2.84)$ & $(-0.90)$ & $(0.76)$ & \\
\hline $\begin{array}{c}- \\
0.00014 \\
4\end{array}$ & $\begin{array}{c}- \\
0.000008 \\
01\end{array}$ & $\begin{array}{c}0.00407 \\
* * *\end{array}$ & $\begin{array}{c}0.00000 \\
158\end{array}$ & $-0.0115^{*}$ & $\begin{array}{c}- \\
0.00001 \\
41\end{array}$ & $\begin{array}{c}0.00158 \\
* * *\end{array}$ & $\begin{array}{c}0.00029 \\
3\end{array}$ & $\begin{array}{c}0.00016 \\
0\end{array}$ & $\begin{array}{c}- \\
0.0006 \\
80\end{array}$ & $\begin{array}{c}0.00679 \\
* * *\end{array}$ & $\begin{array}{c}- \\
0.00001 \\
96\end{array}$ & 0.0121 & $\begin{array}{c}0.00009 \\
35\end{array}$ & $\begin{array}{c}- \\
0.00019 \\
4\end{array}$ & $\begin{array}{c}0.00018 \\
9\end{array}$ & telegram_d \\
\hline$(-0.13)$ & $(-0.01)$ & (14.31) & $(0.04)$ & $(-2.00)$ & $(-0.06)$ & (3.63) & $(1.72)$ & $(1.43)$ & $(-0.54)$ & (7.34) & $(-0.04)$ & $(0.89)$ & $(0.22)$ & $(-1.03)$ & $(0.56)$ & \\
\hline $\begin{array}{c}- \\
0.00362 \\
* * \\
(-2.62)\end{array}$ & $\begin{array}{c}- \\
0.000030 \\
4 \\
(-0.02)\end{array}$ & $\begin{array}{c}- \\
0.00098 \\
4 \\
(-0.40)\end{array}$ & $\begin{array}{c}- \\
0.0171 * \\
* * \\
(-6.86)\end{array}$ & -0.00475 & $\begin{array}{c}0.00078 \\
8 \\
\\
(0.51)\end{array}$ & 0.00164 & $\begin{array}{c}0.00026 \\
7 \\
(0.63)\end{array}$ & $\begin{array}{c}- \\
0.00201 \\
* \\
(-2.24)\end{array}$ & $\begin{array}{c}- \\
0.0019 \\
3 \\
(-0.47)\end{array}$ & $\begin{array}{c}- \\
0.0134 * \\
* * \\
(-4.50)\end{array}$ & $\begin{array}{c}0.00353 \\
* * \\
(2.95)\end{array}$ & 0.00177 & $\begin{array}{c}- \\
0.00158 \\
(-1.57)\end{array}$ & $\begin{array}{c}0.00064 \\
4 \\
\\
(0.71)\end{array}$ & $\begin{array}{c}0.00025 \\
7 \\
(0.18)\end{array}$ & twitter_d \\
\hline $\begin{array}{c}0.00024 \\
4 \\
(0.74)\end{array}$ & 0.000107 & $\begin{array}{c}- \\
0.00056 \\
2 \\
(-1.90)\end{array}$ & $\begin{array}{c}- \\
0.00020 \\
8 \\
(-0.89)\end{array}$ & $\begin{array}{c}- \\
0.00030 \\
8 \\
(-0.65)\end{array}$ & $\begin{array}{c}0.00011 \\
6 \\
(0.51)\end{array}$ & $\begin{array}{c}0.00009 \\
52 \\
(0.51)\end{array}$ & $\begin{array}{c}- \\
0.00005 \\
84 \\
(-0.67)\end{array}$ & $\begin{array}{c}0.00032 \\
9 * \\
(2.58)\end{array}$ & $\begin{array}{c}0.0002 \\
64 \\
(0.70)\end{array}$ & $\begin{array}{c}0.00000 \\
727 \\
(0.03)\end{array}$ & $\begin{array}{c}- \\
0.00056 \\
5^{* *} \\
(-2.64)\end{array}$ & $\begin{array}{c}- \\
0.00007 \\
71 \\
(-0.31)\end{array}$ & $\begin{array}{c}- \\
0.00014 \\
9 \\
(-0.68)\end{array}$ & $\begin{array}{c}0.00002 \\
42 \\
(0.18)\end{array}$ & $\begin{array}{c}- \\
0.00001 \\
03 \\
(-0.12)\end{array}$ & sentiment_d \\
\hline 0.00291 & -0.00339 & $\begin{array}{c}- \\
0.00408\end{array}$ & $\begin{array}{c}0.0111 * \\
* \\
(3.17)\end{array}$ & 0.00363 & -0.00615 & -0.00227 & $\begin{array}{c}- \\
0.00031 \\
0 \\
(-0.19)\end{array}$ & $\begin{array}{c}0.00468 \\
* *\end{array}$ & $\begin{array}{c}0.0002 \\
91 \\
(0.07)\end{array}$ & -0.00410 & $\begin{array}{c}- \\
0.0126 * \\
* * \\
(-5.09)\end{array}$ & $\begin{array}{c}0.00088 \\
8\end{array}$ & 0.00339 & $\begin{array}{c}- \\
0.00269 \\
(-0.72)\end{array}$ & $\begin{array}{c}- \\
0.00045 \\
6 \\
(-0.22)\end{array}$ & $\begin{array}{l}\text { social_volu } \\
\text { me_d }\end{array}$ \\
\hline 0.00117 & 0.000290 & $\begin{array}{c}- \\
0.00045 \\
3 \\
(-0.41) \\
\end{array}$ & $\begin{array}{c}0.00470 \\
* * * \\
\\
(5.55) \\
\end{array}$ & -0.00195 & $\begin{array}{c}0.00139 \\
* \\
\\
(2.04)\end{array}$ & $\begin{array}{c}- \\
0.00247 \\
* * \\
(-3.08)\end{array}$ & $\begin{array}{c}- \\
0.00051 \\
7 \\
(-1.29)\end{array}$ & $\begin{array}{c}- \\
0.00046 \\
4 \\
(-1.17)\end{array}$ & $\begin{array}{c}- \\
0.0002 \\
55 \\
(-0.19) \\
\end{array}$ & $\begin{array}{c}- \\
0.00137 \\
* * \\
(-2.70)\end{array}$ & -0.00106 & $\begin{array}{c}- \\
0.00096 \\
3 \\
(-1.15) \\
\end{array}$ & $\begin{array}{c}- \\
0.00074 \\
3 \\
(-0.79)\end{array}$ & $\begin{array}{c}0.00030 \\
0 \\
(0.49)\end{array}$ & $\begin{array}{c}- \\
0.00011 \\
8 \\
(-0.65)\end{array}$ & _cons \\
\hline 419 & 2572 & 5329 & 5685 & 933 & 6077 & 5507 & 5040 & 5985 & 1702 & 6095 & 5156 & 1723 & 4470 & 5954 & 5937 & $\mathrm{~N}$ \\
\hline
\end{tabular}

$\mathrm{t}$ statistics in parentheses
$* \mathrm{p}<0.05, * * \mathrm{p}<0.01, * * * \mathrm{p}<0.001$ 
Table 3D - model 4 - price

\begin{tabular}{|c|c|c|c|c|c|c|c|c|c|c|c|c|c|c|c|c|}
\hline 16 & 15 & 14 & 13 & 12 & 11 & 10 & 9 & 8 & 7 & 6 & 5 & 4 & 3 & 2 & 1 & \\
\hline- & - & 0.0000 & 0.00172 & 0.0025 & - & 0.00009 & - & - & - & - & - & 0.0008 & - & - & - & negative_d \\
\hline 0.0018 & 0.0008 & 860 & $* *$ & 5 & 0.0005 & 60 & 0.0003 & 0.00020 & 0.0027 & 0.00014 & 0.0000 & 56 & 0.0008 & 0.0001 & 0.0001 & \\
\hline 5 & 52 & & & & 44 & & 40 & 2 & 2 & 9 & 141 & & 38 & 91 & 78 & \\
\hline- & - & 0.0010 & 0.00118 & - & - & - & - & 0.00029 & - & - & - & 0.0011 & - & - & - & positive_d \\
\hline 0.0011 & 0.0021 & 2 & & 0.0005 & 0.0003 & 0.00029 & 0.0002 & 1 & 0.0000 & 0.00414 & 0.0009 & 3 & 0.0007 & 0.0003 & 0.0001 & \\
\hline 4 & 9 & & & 83 & 90 & 3 & 40 & & 661 & $* *$ & 22 & & 89 & 14 & 99 & \\
\hline$(-0.95)$ & $(-1.37)$ & $(1.24)$ & (1.84) & $(-0.40)$ & $(-0.75)$ & $(-0.51)$ & $(-0.89)$ & (1.08) & $(-0.05)$ & $(-2.90)$ & $(-1.34)$ & $(1.01)$ & $(-1.16)$ & $(-0.84)$ & $(-0.28)$ & \\
\hline 0.0021 & - & 0.0009 & 0.00176 & 0.0073 & - & - & - & - & - & - & - & - & - & - & 0.0006 & reddit_d \\
\hline 6 & 0.0023 & 85 & $* *$ & 7 & 0.0039 & 0.00244 & 0.0028 & 0.00266 & 0.0024 & $0.0212^{*}$ & 0.0013 & 0.0030 & 0.0006 & 0.0054 & 02 & \\
\hline & 2 & & & & $5^{* *}$ & & $9 * *$ & $* * *$ & 7 & ** & 9 & 9 & 60 & $8^{*}$ & & \\
\hline$(1.62)$ & $(-1.94)$ & $(1.26)$ & $(2.90)$ & $(0.61)$ & $(-2.78)$ & $(-3.35)$ & $(-2.78)$ & $(-5.35)$ & $(-1.31)$ & $(-11.25)$ & $(-1.38)$ & $(-0.53)$ & $(-0.92)$ & $(-2.00)$ & $(0.55)$ & \\
\hline- & - & - & - & - & 0.0002 & - & 0.0000 & - & - & - & - & - & 0.0005 & - & 0.0008 & telegram_d \\
\hline 0.0005 & 0.0004 & 0.0000 & 0.00000 & 0.0071 & 95 & 0.00143 & 785 & 0.00002 & 0.0002 & 0.00419 & 0.0011 & 0.0002 & 19 & 0.0001 & $61 *$ & \\
\hline 45 & 65 & 982 & 770 & 2 & & $* *$ & & 95 & 23 & $* * *$ & $5^{*}$ & 33 & & 15 & & \\
\hline$(-0.40)$ & $(-0.39)$ & $(-0.32)$ & $(-0.20)$ & $(-0.82)$ & $(1.15)$ & $(-3.16)$ & $(0.41)$ & $(-0.26)$ & $(-0.15)$ & $(-4.47)$ & $(-2.18)$ & $(-0.01)$ & $(1.18)$ & $(-0.59)$ & $(2.54)$ & \\
\hline 0.0018 & - & - & 0.00686 & 0.0106 & 0.0008 & 0.00047 & 0.0003 & - & - & 0.00582 & 0.0020 & - & 0.0015 & - & 0.0015 & twitter_d \\
\hline 3 & $\begin{array}{c}0.0015 \\
1\end{array}$ & $\begin{array}{c}0.0017 \\
4\end{array}$ & ** & & 68 & 7 & 71 & 0.00113 & $\begin{array}{c}0.0007 \\
75\end{array}$ & & 3 & $\begin{array}{c}0.0060 \\
8\end{array}$ & 6 & $\begin{array}{c}0.0005 \\
30\end{array}$ & 6 & \\
\hline$(1.05)$ & $(-0.82)$ & $(-0.66)$ & (2.66) & $(0.46)$ & $(0.55)$ & $(0.44)$ & $(0.79)$ & $(-1.23)$ & $(-0.16)$ & (1.93) & $(1.66)$ & $(-0.33)$ & $(1.47)$ & $(-0.57)$ & $(1.06)$ & \\
\hline
\end{tabular}




\begin{tabular}{|c|c|c|c|c|c|c|c|c|c|c|c|c|c|c|c|c|}
\hline- & 0.0001 & 0.0003 & 0.00017 & - & 0.0003 & 0.00020 & 0.0000 & - & - & 0.00039 & - & - & - & - & - & sentiment_ \\
\hline 0.0006 & 71 & 44 & 8 & 0.0007 & 22 & 6 & 694 & 0.00005 & 0.0007 & 2 & 0.0002 & 0.0000 & 0.0001 & 0.0001 & 0.0000 & d \\
\hline 02 & & & & 36 & & & & 02 & 09 & & 74 & 362 & 06 & 12 & 179 & \\
\hline$(-1.45)$ & $(0.45)$ & $(1.09)$ & $(0.73)$ & $(-1.02)$ & $(1.36)$ & (1.06) & $(0.71)$ & $(-0.39)$ & $(-1.58)$ & (1.53) & $(-1.26)$ & $(-0.10)$ & $(-0.46)$ & $(-0.80)$ & $(-0.21)$ & \\
\hline- & 0.0061 & 0.0082 & - & - & - & - & - & 0.00072 & 0.0027 & 0.00521 & 0.0013 & 0.0054 & - & - & - & social_volu \\
\hline 0.0014 & $5 * *$ & $6 * *$ & $0.0134 *$ & 0.0107 & 0.0034 & 0.00233 & 0.0020 & 0 & 0 & & 6 & 7 & 0.0056 & 0.0010 & 0.0026 & me_d ${ }^{-}$ \\
\hline $\begin{array}{c}6 \\
(-0.74)\end{array}$ & $(2.85)$ & $(2.70)$ & $\begin{array}{c}* * \\
(-3.70)\end{array}$ & $(-0.46)$ & $\begin{array}{c}9 \\
(-1.05)\end{array}$ & $(-0.94)$ & $\begin{array}{c}0 \\
(-1.08)\end{array}$ & $(0.44)$ & $(0.52)$ & (1.20) & $(0.54)$ & $(0.29)$ & $\begin{array}{c}9^{*} \\
(-2.31)\end{array}$ & $\begin{array}{c}4 \\
(-0.27)\end{array}$ & $\begin{array}{c}8 \\
(-1.30)\end{array}$ & \\
\hline- & 0.0020 & - & - & - & 0.0009 & 0.00149 & 0.0006 & 0.00058 & 0.0015 & 0.00121 & 0.0004 & 0.0009 & 0.0009 & 0.0008 & - & _cons \\
\hline 0.0017 & 1 & 0.0013 & 0.00111 & 0.0012 & 94 & & 03 & 2 & 4 & $*$ & 31 & 84 & 76 & 22 & 0.0001 & \\
\hline 3 & & 5 & & 6 & & & & & & & & & & & 48 & \\
\hline$(-1.23)$ & $(1.07)$ & $(-1.14)$ & $(-1.27)$ & $(-0.65)$ & $(1.42)$ & $(1.78)$ & $(1.36)$ & $(1.44)$ & $(0.98)$ & (2.37) & $(0.45)$ & $(0.84)$ & $(0.98)$ & $(1.32)$ & $(-0.82)$ & \\
\hline 413 & 2546 & 5285 & 5637 & 924 & 6029 & 5465 & 5010 & 5937 & 1686 & 6047 & 5108 & 1718 & 4442 & 5908 & 5889 & $\mathrm{~N}$ \\
\hline
\end{tabular}

\begin{tabular}{|c|c|c|c|c|c|c|c|c|c|c|c|c|c|c|c|c|}
\hline 16 & 15 & 14 & 13 & 12 & 11 & 10 & 9 & 8 & 7 & 6 & 5 & 4 & 3 & 2 & 1 & \\
\hline- & 0.0002 & - & - & - & 0.0003 & -0.00127 & 0.000 & - & 0.0001 & - & 0.000 & - & 0.000 & 0.0000 & - & negative \\
\hline 0.0002 & 48 & 0.0002 & 0.00126 & 0.00383 & 45 & & 217 & 0.0001 & 02 & 0.00070 & 281 & 0.0001 & 277 & 591 & 0.0000303 & -d \\
\hline $\begin{array}{c}82 \\
(-0.15)\end{array}$ & $(0.12)$ & $\begin{array}{c}13 \\
(-0.24)\end{array}$ & $\begin{array}{c}* \\
(-1.98)\end{array}$ & $(-1.44)$ & $(0.76)$ & $(-1.49)$ & $(0.71)$ & $\begin{array}{c}69 \\
(-0.62)\end{array}$ & $(0.03)$ & $\begin{array}{c}1 \\
(-1.83)\end{array}$ & $(0.35)$ & $\begin{array}{c}34 \\
(-0.09)\end{array}$ & $(0.28)$ & $(0.15)$ & & \\
\hline 0.0002 & 0.0011 & 0.0010 & 0.00176 & 0.00254 & - & 0.00034 & 0.000 & - & - & -0.00248 & 0.000 & 0.0005 & - & - & 0.000251 & positive_ \\
\hline 79 & 3 & 7 & $* *$ & & 0.0011 & 8 & 0410 & 0.0000 & 0.0020 & & 110 & 68 & 0.000 & 0.0003 & & d \\
\hline$(0.21)$ & $(0.72)$ & $(1.35)$ & $(2.72)$ & $(1.62)$ & $\begin{array}{c}8^{*} \\
(-2.24)\end{array}$ & $(0.57)$ & $(0.15)$ & $\begin{array}{c}744 \\
(-0.28)\end{array}$ & $\begin{array}{c}5 \\
(-1.25)\end{array}$ & $(-1.69)$ & $(0.15)$ & $(0.55)$ & $\begin{array}{c}307 \\
(- \\
0.42)\end{array}$ & $\begin{array}{c}47 \\
(-0.93)\end{array}$ & $(0.35)$ & \\
\hline
\end{tabular}




\begin{tabular}{|c|c|c|c|c|c|c|c|c|c|c|c|c|c|c|c|c|}
\hline - & - & 0.0010 & 0.00069 & 0.00388 & 0.0119 & 0.00112 & 0.002 & 0.0051 & 0.0008 & 0.00376 & - & - & 0.000 & 0.0002 & -0.00128 & reddit_d \\
\hline 0.0000 & 0.0013 & 1 & 0 & & $* * *$ & & $82 * *$ & $9 * * *$ & 03 & & 0.000 & 0.0036 & 533 & 06 & & \\
\hline $\begin{array}{c}828 \\
(-0.06)\end{array}$ & $\begin{array}{c}5 \\
(-1.17)\end{array}$ & $(1.34)$ & (1.13) & $(0.30)$ & $(8.32)$ & (1.44) & $(2.74)$ & (10.57) & $(0.32)$ & (1.94) & $\begin{array}{c}682 \\
(- \\
0.64)\end{array}$ & $\begin{array}{c}5 \\
(-0.68)\end{array}$ & $(0.70)$ & $(0.08)$ & $(-1.17)$ & \\
\hline - & 0.0014 & 0.0006 & 0.00000 & -0.0132 & - & - & - & - & - & 0.00099 & 0.000 & - & - & 0.0000 & - & telegram \\
\hline 0.0004 & 1 & $99 *$ & 489 & & 0.0006 & 0.00076 & 0.000 & 0.0002 & 0.0004 & 8 & 343 & 0.0007 & 0.000 & 834 & 0.0000087 & _d \\
\hline $\begin{array}{c}55 \\
(-0.30)\end{array}$ & $(1.21)$ & $(2.39)$ & $(0.13)$ & $(-1.39)$ & $\begin{array}{c}75^{* *} \\
(-2.60)\end{array}$ & $\begin{array}{c}4 \\
(-1.58)\end{array}$ & $\begin{array}{c}146 \\
(- \\
0.77)\end{array}$ & $\begin{array}{c}63^{*} \\
(-2.35)\end{array}$ & $\begin{array}{c}41 \\
(-0.22)\end{array}$ & $(1.04)$ & $(0.62)$ & $\begin{array}{c}92 \\
(-0.05)\end{array}$ & $\begin{array}{c}138 \\
(- \\
0.29)\end{array}$ & $(0.43)$ & $\begin{array}{c}7 \\
(-0.03)\end{array}$ & \\
\hline - & - & - & $0.0108 *$ & - & 0.0058 & 0.00105 & 0.000 & 0.0017 & - & $0.0151^{*}$ & - & - & - & - & 0.00136 & twitter_d \\
\hline 0.0013 & 0.0002 & 0.0034 & $* *$ & 0.00012 & $8 * * *$ & & 0897 & 8 & 0.0011 & $* *$ & 0.001 & 0.0053 & 0.000 & 0.0006 & & \\
\hline 2 & 62 & 9 & & 4 & & & & & 8 & & 16 & 1 & 120 & 03 & & \\
\hline$(-0.68)$ & $(-0.15)$ & $(-1.37)$ & (4.17) & $(-0.00)$ & $(3.70)$ & $(0.91)$ & $(0.19)$ & $(1.96)$ & $(-0.18)$ & $(4.86)$ & $\begin{array}{c}(- \\
0.90)\end{array}$ & $(-0.31)$ & $\begin{array}{c}(- \\
0.11)\end{array}$ & $(-0.65)$ & $(0.91)$ & \\
\hline 0.0002 & 0.0000 & - & 0.00016 & 0.00154 & - & - & 0.000 & 0.0001 & 0.0018 & - & - & - & - & - & - & sentimen \\
\hline 96 & 785 & 0.0002 & 6 & $*$ & 0.0000 & 0.00011 & $213^{*}$ & 16 & $1 * *$ & 0.00005 & 0.000 & 0.0000 & 0.000 & 0.0000 & 0.0000486 & $\mathrm{t} \_\mathrm{d}$ \\
\hline$(0.65)$ & $(0.22)$ & $\begin{array}{c}32 \\
(-0.76)\end{array}$ & $(0.68)$ & (1.98) & $\begin{array}{c}821 \\
(-0.34)\end{array}$ & $\begin{array}{c}6 \\
(-0.57)\end{array}$ & $(2.18)$ & $(0.91)$ & (2.99) & $\begin{array}{c}92 \\
(-0.23)\end{array}$ & $\begin{array}{c}451^{*} \\
(- \\
1.97)\end{array}$ & $\begin{array}{c}372 \\
(-0.12)\end{array}$ & $\begin{array}{c}243 \\
(- \\
1.00)\end{array}$ & $\begin{array}{c}0867 \\
(-0.06)\end{array}$ & $(-0.56)$ & \\
\hline 0.0027 & 0.0001 & 0.0086 & - & - & - & -0.00473 & - & - & 0.0046 & - & 0.005 & 0.0055 & - & 0.0060 & 0.000357 & social_v \\
\hline 1 & 46 & $6 * *$ & $\begin{array}{c}0.0138 * \\
* *\end{array}$ & $\begin{array}{c}0.00068 \\
3\end{array}$ & $\begin{array}{c}0.0152 \\
* * *\end{array}$ & & $\begin{array}{l}0.005 \\
04 * *\end{array}$ & $\begin{array}{c}0.0085 \\
2 * * *\end{array}$ & 1 & $\begin{array}{c}0.0146^{*} \\
*\end{array}$ & $31 *$ & 6 & $\begin{array}{c}0.002 \\
82\end{array}$ & 6 & & olume_d \\
\hline$(1.22)$ & $(0.07)$ & $(2.95)$ & $(-3.79)$ & $(-0.03)$ & $(-4.52)$ & $(-1.80)$ & $\begin{array}{c}(- \\
2.74)\end{array}$ & $(-5.31)$ & $(0.66)$ & $(-3.28)$ & (1.99) & $(0.32)$ & $\begin{array}{c}(- \\
1.08)\end{array}$ & $(1.58)$ & $(0.17)$ & \\
\hline - & - & - & - & 0.00089 & - & 0.00064 & 0.000 & - & - & 0.00014 & 0.000 & 0.0004 & 0.001 & - & -0.000144 & _cons \\
\hline 0.0005 & 0.0014 & 0.0024 & 0.00057 & 2 & 0.0003 & 3 & 0540 & 0.0001 & 0.0013 & 7 & 185 & 71 & 18 & 0.0000 & & \\
\hline $\begin{array}{c}41 \\
(-0.34)\end{array}$ & $\begin{array}{c}3 \\
(-0.78)\end{array}$ & $\begin{array}{c}5^{*} \\
(-2.14)\end{array}$ & $\begin{array}{c}5 \\
(-0.65)\end{array}$ & $(0.42)$ & $\begin{array}{c}71 \\
(-0.52)\end{array}$ & $(0.72)$ & $(0.12)$ & $\begin{array}{c}45 \\
(-0.36)\end{array}$ & $\begin{array}{c}3 \\
(-0.63)\end{array}$ & $(0.28)$ & $(0.18)$ & $(0.44)$ & (1.11) & $\begin{array}{c}140 \\
(-0.02)\end{array}$ & $(-0.80)$ & \\
\hline 387 & 2480 & 5195 & 5541 & 901 & 5933 & 5374 & 4924 & 5841 & 1648 & 5951 & 5019 & 1696 & 4357 & 5812 & 5793 & $\mathrm{~N}$ \\
\hline
\end{tabular}


Table 4A - model 1 - Volume

\begin{tabular}{|c|c|c|c|c|c|c|c|c|c|c|c|c|c|c|c|c|}
\hline 16 & 15 & 14 & 13 & 12 & 11 & 10 & 9 & 8 & 7 & 6 & 5 & 4 & 3 & 2 & 1 & \\
\hline $\begin{array}{l}-0.149 \\
(-1.06)\end{array}$ & $\begin{array}{c}28.51^{* *} \\
* \\
(4.09)\end{array}$ & $\begin{array}{c}- \\
33219.2 \\
(-0.54)\end{array}$ & $\begin{array}{c}- \\
54427.5 \\
(-0.49)\end{array}$ & $\begin{array}{l}0.0621 \\
(0.48)\end{array}$ & $\begin{array}{c}-477.2 \\
(- \\
0.45)\end{array}$ & $\begin{array}{l}0.444 \\
(0.03)\end{array}$ & $\begin{array}{l}0.460 \\
(0.62)\end{array}$ & $\begin{array}{c}-2.637 \\
(- \\
0.91)\end{array}$ & $\begin{array}{l}-0.0429 \\
(-0.36)\end{array}$ & $\begin{array}{l}0.140 \\
(0.04)\end{array}$ & $\begin{array}{c}-41.59 \\
(- \\
0.47)\end{array}$ & $\begin{array}{c}0.087 \\
8 \\
(1.91)\end{array}$ & $\begin{array}{r}-2037.8 \\
(-0.77)\end{array}$ & $\begin{array}{l}-0.113 \\
(-0.69)\end{array}$ & $\begin{array}{l}-0.115 \\
(-0.12)\end{array}$ & negative_d \\
\hline 0.0669 & $(-1.14)$ & $\begin{array}{c}- \\
15619.1 \\
(-0.28)\end{array}$ & $\begin{array}{c}- \\
38764.8 \\
(-0.35)\end{array}$ & -0.0663 & 240.6 & -11.94 & -0.259 & $\begin{array}{c}-0.235 \\
(- \\
0.08)\end{array}$ & $\begin{array}{c}- \\
0.0091 \\
1 \\
(-0.14)\end{array}$ & 1.926 & $\begin{array}{c}186.1 \\
* \\
(2.28)\end{array}$ & $\begin{array}{c}- \\
0.011 \\
5 \\
(- \\
0.36)\end{array}$ & 2935.0 & 0.00812 & -0.915 & positive_d \\
\hline 0.0916 & $\begin{array}{c}34.97 * * \\
*\end{array}$ & 15652.2 & $\begin{array}{c}- \\
28953.7\end{array}$ & 0.691 & $\begin{array}{c}- \\
1165 . \\
0 \\
(- \\
0.34)\end{array}$ & -11.07 & -3.171 & $\begin{array}{c}(- \\
0.24)\end{array}$ & 0.0255 & 5.027 & 125.3 & $\begin{array}{c}0.001 \\
06\end{array}$ & -893.2 & -0.666 & $\begin{array}{c}8.231 * \\
* \\
(2.77)\end{array}$ & reddit_d \\
\hline-0.0956 & $9.773 *$ & 821.1 & -251.2 & $\begin{array}{c}3.910 * * \\
*\end{array}$ & 260.8 & $24.81^{*}$ & -0.200 & $\begin{array}{c}(- \\
0.22)\end{array}$ & 0.0345 & -2.541 & 9.167 & $\begin{array}{c}- \\
0.071 \\
3 \\
(- \\
0.13)\end{array}$ & $\begin{array}{c}2889.1 \\
* \\
(2.31)\end{array}$ & $\begin{array}{c}0.00063 \\
2 \\
(0.01)\end{array}$ & $\begin{array}{l}-0.452 \\
(-0.49)\end{array}$ & telegram_d \\
\hline-0.0317 & (1.37) & $\begin{array}{c}- \\
155357 \\
7 \\
(-0.88)\end{array}$ & $\begin{array}{c}- \\
60246.4 \\
(-0.13)\end{array}$ & $\begin{array}{l}1.616 \\
(1.31)\end{array}$ & $\begin{array}{c}- \\
1624 . \\
7 \\
(- \\
0.43)\end{array}$ & -2.591 & $(-0.87)$ & $\begin{array}{c}(- \\
0.67)\end{array}$ & -0.0631 & $\begin{array}{l}43.65 \\
(1.62)\end{array}$ & $(0.84)$ & $\begin{array}{c}0.017 \\
4 \\
(0.03)\end{array}$ & $(0.37)$ & $\begin{array}{c}0.00257 \\
(0.01)\end{array}$ & $\begin{array}{c}10.84 * \\
* \\
(2.72)\end{array}$ & twitter_d \\
\hline-0.0355 & -0.750 & 2339.8 & -4055.1 & 0.0137 & $\begin{array}{c}(- \\
0.12)\end{array}$ & -0.925 & -0.0671 & 0.466 & -0.0146 & -0.797 & $\begin{array}{c}(- \\
0.25)\end{array}$ & $\begin{array}{c}- \\
0.001 \\
33 \\
(- \\
0.13)\end{array}$ & -249.8 & $\begin{array}{c}- \\
0.00015 \\
6 \\
(-0.00)\end{array}$ & -0.0940 & sentiment_d \\
\hline 0.0418 & $22.08^{* *}$ & $\begin{array}{c}139376 . \\
2\end{array}$ & $\begin{array}{c}- \\
27513.0\end{array}$ & -1.281 & $\begin{array}{c}1034 . \\
3\end{array}$ & 17.90 & 4.830 & 7.551 & 0.0998 & -51.59 & -280.2 & $\begin{array}{c}0.000 \\
580\end{array}$ & -994.0 & 0.195 & -9.732 & $\begin{array}{l}\text { social_volume } \\
\text { _d }\end{array}$ \\
\hline
\end{tabular}




\begin{tabular}{|c|c|c|c|c|c|c|c|c|c|c|c|c|c|c|c|c|}
\hline$(0.25)$ & $(-3.00)$ & $(0.68)$ & $(-0.04)$ & $(-1.04)$ & $(0.13)$ & $(0.34)$ & (1.09) & $(0.45)$ & $(0.35)$ & $(-1.34)$ & $\begin{array}{c}(- \\
0.94)\end{array}$ & $(0.00)$ & $(-0.14)$ & $(0.12)$ & $(-1.74)$ & \\
\hline $\begin{array}{c}0.549 * * \\
*\end{array}$ & -11.38 & 96264.5 & $\begin{array}{c}218292 \\
7\end{array}$ & $0.229 *$ & $\begin{array}{c}2491 . \\
9\end{array}$ & 21.62 & $2.502 *$ & 8.183 & $\begin{array}{c}0.381 * \\
* *\end{array}$ & 6.085 & 67.82 & $\begin{array}{c}0.165 \\
* * *\end{array}$ & 1043.5 & $0.678^{*}$ & 0.879 & _cons \\
\hline$(4.56)$ & $(-1.78)$ & $(1.22)$ & (1.42) & $(2.22)$ & $(1.49)$ & $(1.20)$ & $(2.34)$ & (1.94) & $(4.50)$ & $(1.33)$ & $(0.60)$ & $(4.95)$ & $(0.37)$ & $(2.51)$ & $(1.78)$ & \\
\hline 424 & 2577 & 5345 & 5709 & 934 & 6101 & 5529 & 5054 & 6009 & 1704 & 6119 & 5176 & 1727 & 4490 & 5976 & 5961 & $\mathrm{~N}$ \\
\hline
\end{tabular}

$\mathrm{t}$ statistics in parentheses

$* \mathrm{p}<0.05, * * \mathrm{p}<0.01, * * * \mathrm{p}<0.001$

Table 4B - model 2 - Volume

\begin{tabular}{|c|c|c|c|c|c|c|c|c|c|c|c|c|c|c|c|c|}
\hline 16 & 15 & 14 & 13 & 12 & 11 & 10 & 9 & 8 & 7 & 6 & 5 & 4 & 3 & 2 & 1 & \\
\hline 0.0266 & -0.0135 & 0.0103 & -0.0101 & 0.0360 & $\begin{array}{c}- \\
0.00875 \\
(-0.53)\end{array}$ & 0.00303 & 0.00809 & $\begin{array}{c}- \\
0.00079 \\
6 \\
(-0.15)\end{array}$ & -0.0454 & 0.00989 & $\begin{array}{c}- \\
0.00070 \\
9 \\
(-0.05)\end{array}$ & -0.0574 & 0.0194 & -0.0124 & $\begin{array}{c}- \\
0.00792 \\
(-0.42)\end{array}$ & negative_d \\
\hline $\begin{array}{l}-0.0469 \\
(-0.49)\end{array}$ & $\begin{array}{c}- \\
0.0762 * \\
(-2.21)\end{array}$ & $\begin{array}{l}-0.0151 \\
(-0.73)\end{array}$ & $\begin{array}{c}- \\
0.00472 \\
(-0.33)\end{array}$ & $\begin{array}{c}-0.0903 \\
(-1.16)\end{array}$ & $\begin{array}{l}0.0154 \\
(0.81)\end{array}$ & $\begin{array}{c}- \\
0.00776 \\
(-0.84)\end{array}$ & $\begin{array}{c}0.00479 \\
(0.51)\end{array}$ & 0.00335 & $\begin{array}{l}0.0726 \\
(1.13)\end{array}$ & 0.0224 & $\begin{array}{c}0.00823 \\
(0.69)\end{array}$ & $\begin{array}{l}0.0116 \\
(0.34)\end{array}$ & $\begin{array}{c}- \\
0.00134 \\
(-0.07)\end{array}$ & $\begin{array}{c}- \\
0.00401 \\
(-0.46)\end{array}$ & $\begin{array}{l}0.0140 \\
(0.38)\end{array}$ & positive_d \\
\hline-0.0233 & -0.0189 & 0.0135 & $\begin{array}{c}- \\
0.00011 \\
8 \\
(-0.14)\end{array}$ & -0.0701 & $\begin{array}{c}- \\
0.00444 \\
(-0.47)\end{array}$ & $\begin{array}{c}- \\
0.00452 \\
(-0.63)\end{array}$ & $\begin{array}{c}0.00063 \\
9 \\
(0.10)\end{array}$ & $\begin{array}{c}- \\
0.00045 \\
8 \\
(-0.20)\end{array}$ & -0.0683 & -0.0136 & -0.0121 & 0.0882 & 0.00751 & $\begin{array}{c}- \\
0.00657 \\
(-1.43)\end{array}$ & $\begin{array}{c}- \\
0.0443 * \\
(-2.54)\end{array}$ & telegram_d \\
\hline $\begin{array}{l}0.195 \\
(1.41)\end{array}$ & $\begin{array}{l}0.0265 \\
(0.67)\end{array}$ & $\begin{array}{c}0.00086 \\
7 \\
(0.01)\end{array}$ & $\begin{array}{c}- \\
0.00437 \\
(-0.08)\end{array}$ & $(-0.26)$ & 0.00958 & $\begin{array}{l}0.0112 \\
(0.66)\end{array}$ & $\begin{array}{c}- \\
0.00763 \\
(-0.47)\end{array}$ & $\begin{array}{c}0.00753 \\
(0.42)\end{array}$ & $\begin{array}{c}-0.0785 \\
(-0.31)\end{array}$ & $\begin{array}{c}-0.00417 \\
(-0.07)\end{array}$ & $\begin{array}{c}0.00155 \\
(0.07)\end{array}$ & $\begin{array}{l}0.335 \\
(0.59)\end{array}$ & $\begin{array}{c}0.00863 \\
(0.31)\end{array}$ & $\begin{array}{l}0.0186 \\
(0.85)\end{array}$ & $\begin{array}{l}0.0847 \\
(1.12)\end{array}$ & twitter_d \\
\hline-0.0102 & $\begin{array}{c}0.00051 \\
9\end{array}$ & 0.00267 & $\stackrel{-}{-}$ & -0.0116 & $\stackrel{-}{-}$ & $\stackrel{-}{-}$ & 0.00142 & -0.00161 & 0.0255 & -0.00580 & $\stackrel{-}{-}$ & $\stackrel{-}{-}$ & $\begin{array}{c}- \\
0.00234\end{array}$ & $\begin{array}{c}- \\
0.00087 \\
7\end{array}$ & 0.00412 & sentiment_d \\
\hline
\end{tabular}




\begin{tabular}{|c|c|c|c|c|c|c|c|c|c|c|c|c|c|c|c|c|}
\hline$(-0.30)$ & $(0.06)$ & $(0.33)$ & $(-0.73)$ & $(-0.30)$ & $(-0.78)$ & $(-0.38)$ & $(0.42)$ & $(-0.63)$ & (1.09) & $(-1.16)$ & $(-0.39)$ & $(-0.90)$ & $(-0.39)$ & $(-0.26)$ & $(0.91)$ & \\
\hline 0.0148 & 0.00418 & 0.122 & -0.0566 & 0.329 & -0.0396 & 0.00180 & $\begin{array}{c}- \\
0.00273\end{array}$ & -0.0288 & 0.0884 & -0.0899 & -0.0360 & -0.331 & -0.0620 & -0.0220 & $-0.231 *$ & $\begin{array}{l}\text { social_volum } \\
\text { e d }\end{array}$ \\
\hline$(0.09)$ & $(0.09)$ & $(1.56)$ & $(-0.71)$ & $(0.26)$ & $(-0.32)$ & $(0.05)$ & $(-0.04)$ & $(-0.90)$ & $(0.32)$ & $(-1.07)$ & $(-0.81)$ & $(-0.59)$ & $(-0.97)$ & $(-0.24)$ & $(-2.18)$ & \\
\hline $0.473^{* *}$ & $0.403 * *$ & $0.266 * *$ & $0.198 * *$ & $0.374 * *$ & $0.141 * *$ & $0.144 * *$ & $0.185^{* *}$ & $0.0658^{*}$ & $0.367 * *$ & $0.0692 *$ & $0.140^{* *}$ & $0.192 * *$ & $0.141^{* *}$ & $0.149 * *$ & $0.122 * *$ & _cons \\
\hline * & $*$ & $*$ & $*$ & $*$ & $*$ & * & $*$ & $* *$ & $*$ & $* *$ & $*$ & $*$ & $*$ & $*$ & $*$ & \\
\hline$(4.17)$ & $(9.88)$ & $(8.84)$ & (10.23) & $(3.59)$ & $(5.48)$ & $(10.82)$ & $(12.00)$ & $(8.26)$ & $(4.46)$ & $(6.92)$ & $(8.38)$ & $(5.41)$ & $(5.39)$ & (10.09) & (13.08) & \\
\hline 422 & 2558 & 5298 & 5659 & 933 & 6049 & 5479 & 5011 & 5959 & 1691 & 6067 & 5134 & 1706 & 4456 & 5927 & 5909 & $\mathrm{~N}$ \\
\hline
\end{tabular}

$\mathrm{t}$ statistics in parentheses

$* \mathrm{p}<0.05, * * \mathrm{p}<0.01, * * * \mathrm{p}<0.001$

Table 4C - model 3 - Volume

\begin{tabular}{|c|c|c|c|c|c|c|c|c|c|c|c|c|c|c|c|c|}
\hline 16 & 15 & 14 & 13 & 12 & 11 & 10 & 9 & 8 & 7 & 6 & 5 & 4 & 3 & 2 & 1 & \\
\hline-0.0787 & $\begin{array}{c}0.0040 \\
3\end{array}$ & -0.0176 & $\begin{array}{c}- \\
0.00772\end{array}$ & -0.0144 & -0.0122 & -0.0104 & -0.0122 & $\begin{array}{c}0.00016 \\
6\end{array}$ & -0.113 & $0.0163^{*}$ & 0.0165 & -0.0318 & 0.0278 & $\begin{array}{c}0.0067 \\
2\end{array}$ & $\begin{array}{c}0.0461 \\
*\end{array}$ & negative_d \\
\hline$(-0.77)$ & $(0.08)$ & $(-0.71)$ & $(-0.55)$ & $(-0.09)$ & $(-0.75)$ & $(-0.79)$ & $(-1.21)$ & $(0.03)$ & $(-0.88)$ & $(2.23)$ & (1.38) & $(-0.63)$ & $(1.15)$ & $(0.73)$ & $(2.41)$ & \\
\hline 0.0330 & -0.0117 & $\begin{array}{c}0.0091 \\
0\end{array}$ & -0.0113 & $\begin{array}{c}0.0066 \\
6\end{array}$ & -0.0125 & $\begin{array}{c}0.0025 \\
9\end{array}$ & 0.00280 & -0.00518 & -0.0307 & 0.00517 & $\begin{array}{c}0.0024 \\
0\end{array}$ & 0.0245 & -0.0215 & $\begin{array}{c}- \\
0.0034\end{array}$ & 0.0370 & positive_d \\
\hline$(0.45)$ & $(-0.32)$ & $(0.42)$ & $(-0.81)$ & $(0.07)$ & $(-0.65)$ & $(0.27)$ & $(0.32)$ & $(-0.97)$ & $(-0.43)$ & $(0.18)$ & $(0.22)$ & $(0.70)$ & $(-1.21)$ & $\begin{array}{c}6 \\
(-0.39)\end{array}$ & $(1.01)$ & \\
\hline-0.0393 & -0.0539 & -0.0181 & 0.0156 & -0.0906 & -0.0129 & -0.0144 & -0.0126 & $\begin{array}{c}- \\
0.0294 * \\
*\end{array}$ & 0.00565 & $-0.0909 *$ & 0.0254 & 0.0329 & $\begin{array}{c}0.0015 \\
8\end{array}$ & 0.0483 & $\begin{array}{c}0.0021 \\
3\end{array}$ & reddit_d \\
\hline$(-0.48)$ & $(-1.94)$ & $(-0.87)$ & (1.17) & $(-0.12)$ & $(-0.25)$ & $(-1.20)$ & $(-0.37)$ & $(-3.00)$ & $(0.05)$ & $(-2.47)$ & (1.57) & $(0.18)$ & $(0.08)$ & $(0.73)$ & $(0.04)$ & \\
\hline-0.0153 & 0.0075 & $0.111^{*}$ & 0.00032 & 0.207 & 0.0031 & 0.0060 & - & -0.00212 & -0.0823 & -0.00254 & 0.0063 & 0.715 & 0.0081 & - & 0.0133 & telegram_d \\
\hline$(-0.18)$ & $\begin{array}{c}8 \\
(0.27)\end{array}$ & $\begin{array}{c}* * \\
(13.69)\end{array}$ & (0.39) & $(0.37)$ & $\begin{array}{c}5 \\
(0.33)\end{array}$ & $\begin{array}{c}4 \\
(0.81)\end{array}$ & $\begin{array}{c}0.00009 \\
20 \\
(-0.01)\end{array}$ & $(-0.95)$ & $(-0.96)$ & $(-0.14)$ & $\begin{array}{c}3 \\
(0.75)\end{array}$ & $(1.21)$ & $\begin{array}{c}1 \\
(0.70)\end{array}$ & $\begin{array}{c}0.0007 \\
48 \\
(-0.16)\end{array}$ & $(0.75)$ & \\
\hline-0.0108 & -0.0201 & 0.0194 & 0.0149 & -0.318 & 0.0419 & -0.0241 & 0.0123 & -0.0149 & 0.0920 & -0.0832 & -0.0182 & -0.314 & $\begin{array}{c}0.0015 \\
6\end{array}$ & $\begin{array}{c}0.0011 \\
0\end{array}$ & -0.0679 & twitter_d \\
\hline$(-0.10)$ & $(-0.47)$ & $(0.28)$ & $(0.26)$ & $(-0.21)$ & $(0.73)$ & $(-1.37)$ & $(0.80)$ & $(-0.83)$ & $(0.33)$ & $(-1.40)$ & $(-0.93)$ & $(-0.54)$ & $(0.06)$ & $(0.05)$ & $(-0.89)$ & \\
\hline
\end{tabular}




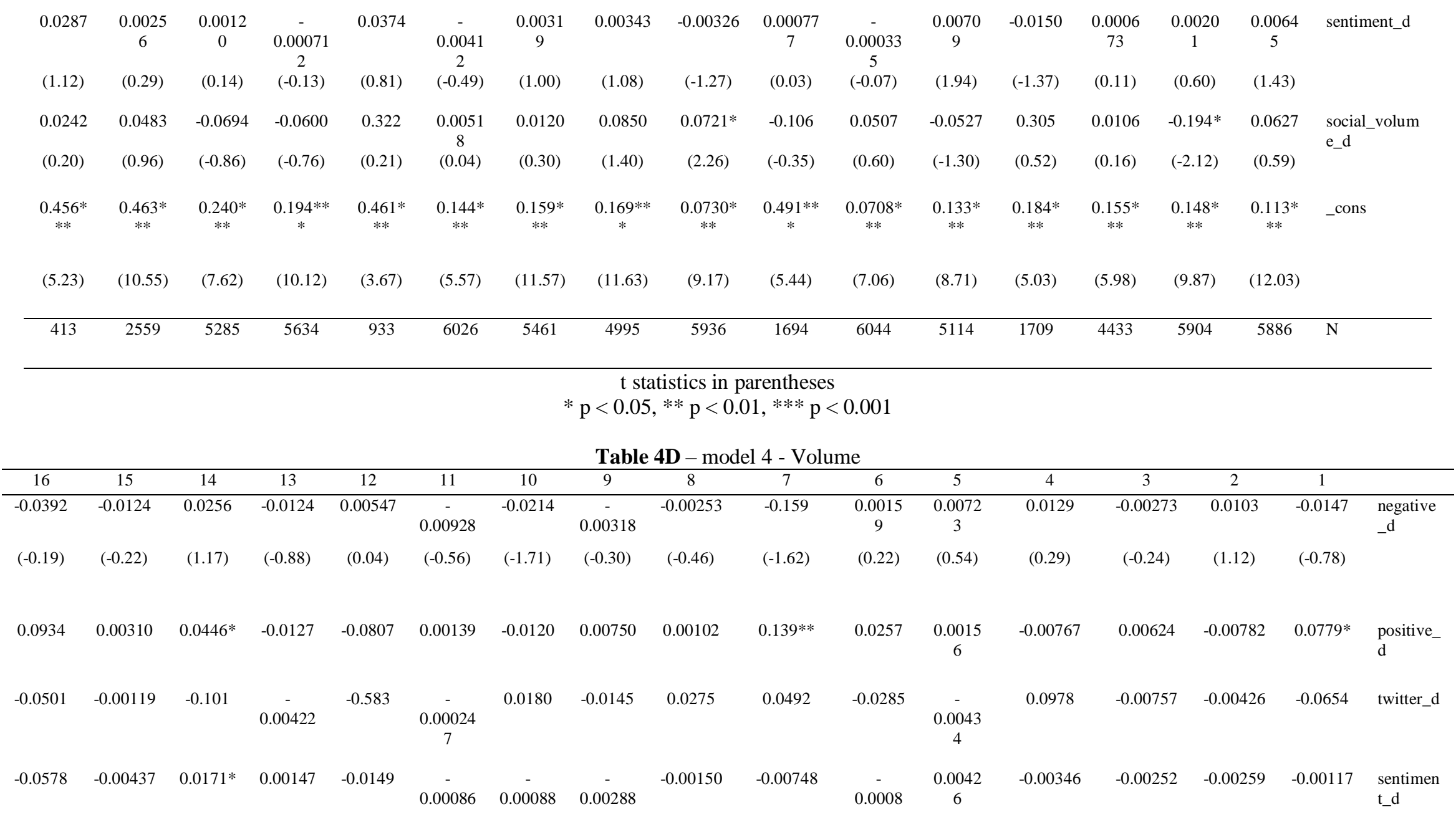




\begin{tabular}{|c|c|c|c|c|c|c|c|c|c|c|c|c|c|c|c|c|}
\hline$(-1.12)$ & $(-0.41)$ & $(2.28)$ & $(0.27)$ & $(-0.40)$ & $\begin{array}{c}9 \\
(-0.10)\end{array}$ & $\begin{array}{c}3 \\
(-0.29)\end{array}$ & $(-0.86)$ & $(-0.58)$ & $(-0.38)$ & $\begin{array}{c}35 \\
(-0.17)\end{array}$ & $(1.09)$ & $(-0.35)$ & $(-0.86)$ & $(-0.76)$ & $(-0.26)$ & \\
\hline-0.0981 & -0.00761 & 0.138 & 0.0383 & 0.617 & 0.00413 & -0.0373 & -0.0622 & -0.0217 & -0.0654 & $\begin{array}{c}0.0015 \\
4\end{array}$ & -0.0205 & -0.0563 & 0.0141 & -0.0131 & 0.0819 & $\begin{array}{l}\text { social_v } \\
\text { olume_d }\end{array}$ \\
\hline$(-0.40)$ & $(-0.13)$ & $(1.92)$ & $(0.48)$ & $(0.51)$ & $(0.03)$ & $(-0.96)$ & $(-0.97)$ & $(-0.67)$ & $(-0.29)$ & $(0.02)$ & $(-0.45)$ & $(-0.11)$ & $(0.46)$ & $(-0.14)$ & $(0.79)$ & \\
\hline $0.794 * *$ & $0.443 * *$ & $0.244 * *$ & $0.204 * *$ & $0.425 * *$ & $0.147 * *$ & $0.142 * *$ & $0.197 * *$ & $0.0650^{*}$ & $0.499 * * *$ & 0.0659 & $0.138^{*}$ & $0.141 * * *$ & $0.123 * *$ & $0.135^{* *}$ & $0.114 * *$ & _cons \\
\hline$*$ & $*$ & $*$ & $*$ & $*$ & $*$ & $*$ & $*$ & $* *$ & & $* * *$ & $* *$ & & $*$ & $*$ & * & \\
\hline$(4.49)$ & $(8.35)$ & $(8.70)$ & $(10.46)$ & $(4.20)$ & $(5.67)$ & $(10.83)$ & $(12.84)$ & $(8.10)$ & $(7.28)$ & $(6.53)$ & $(8.01)$ & $(4.30)$ & $(10.06)$ & $(8.98)$ & $(12.51)$ & \\
\hline 411 & 2524 & 5243 & 5586 & 923 & 5978 & 5423 & 4972 & 5886 & 1682 & 5996 & 5063 & 1715 & 4404 & 5857 & 5838 & $\mathrm{~N}$ \\
\hline
\end{tabular}

Table 4E - model 5 - Volume

\begin{tabular}{|c|c|c|c|c|c|c|c|c|c|c|c|c|c|c|c|c|}
\hline 16 & 15 & 14 & 13 & 12 & 11 & 10 & 9 & 8 & 7 & 6 & 5 & 4 & 3 & 2 & 1 & \\
\hline $\begin{array}{c}- \\
0.0158 \\
(-0.10)\end{array}$ & 0.0553 & -0.0169 & 0.00504 & 0.0270 & $\begin{array}{c}0.0014 \\
1 \\
(0.17)\end{array}$ & 0.0143 & 0.0105 & $\begin{array}{c}- \\
0.00235 \\
(-0.44)\end{array}$ & -0.0627 & 0.00200 & $\begin{array}{c}0.0038 \\
2\end{array}$ & 0.0691 & $\begin{array}{c}0.0258 \\
* \\
(2.20)\end{array}$ & $\begin{array}{c}- \\
0.0015 \\
6 \\
(-0.23)\end{array}$ & 0.0206 & negative_d \\
\hline $\begin{array}{c}- \\
0.0575 \\
(-0.49)\end{array}$ & $\begin{array}{c}- \\
0.0143 \\
(-0.30)\end{array}$ & 0.0207 & $\begin{array}{c}0.0527 * \\
* *\end{array}$ & $\begin{array}{c}- \\
0.0186 \\
(-0.18)\end{array}$ & $\begin{array}{c}- \\
0.0033 \\
0 \\
(-0.34)\end{array}$ & 0.0111 & 0.00643 & 0.00523 & 0.0199 & -0.0270 & 0.0119 & 0.0478 & $\begin{array}{c}- \\
0.0009 \\
92 \\
(-0.11)\end{array}$ & $\begin{array}{c}- \\
0.0011 \\
4 \\
(-0.17)\end{array}$ & 0.0193 & positive_d \\
\hline 0.0596 & $\begin{array}{c}- \\
0.0065 \\
4 \\
(-0.19)\end{array}$ & 0.0162 & 0.0164 & $(0.29)$ & 0.0481 & $(1.56)$ & -0.0408 & 0.0122 & -0.0557 & $\begin{array}{c}0.123^{* *} \\
* \\
(3.72)\end{array}$ & $\begin{array}{c}- \\
0.0254 \\
(-1.70)\end{array}$ & $(-0.53)$ & 0.0113 & $(0.52)$ & $\begin{array}{c}0.0062 \\
1 \\
(0.11)\end{array}$ & reddit_d \\
\hline $\begin{array}{c}- \\
0.0615 \\
(-0.46)\end{array}$ & $\begin{array}{c}- \\
0.0304 \\
(-0.87)\end{array}$ & $\begin{array}{c}0.0006 \\
38 \\
(0.09)\end{array}$ & $\begin{array}{c}- \\
0.00033 \\
7 \\
(-0.38)\end{array}$ & $\begin{array}{c}- \\
0.0790 \\
(-0.13)\end{array}$ & $\begin{array}{l}0.0055 \\
5 \\
(1.16)\end{array}$ & 0.0114 & $\begin{array}{c}- \\
0.00518\end{array}$ & $\begin{array}{c}- \\
0.00132 \\
(-0.60)\end{array}$ & -0.0314 & 0.0238 & $\begin{array}{c}- \\
0.0164 \\
* \\
(-2.09)\end{array}$ & -0.833 & $\begin{array}{c}0.0033 \\
4 \\
\\
(0.60)\end{array}$ & $\begin{array}{c}0.0026 \\
9 \\
(0.78)\end{array}$ & 0.0172 & telegram_d \\
\hline $\begin{array}{c}- \\
0.0121\end{array}$ & 0.0525 & 0.0376 & 0.0643 & 0.140 & 0.0368 & $\begin{array}{c}- \\
0.0010 \\
5\end{array}$ & $\begin{array}{c}- \\
0.00008 \\
87\end{array}$ & -0.0181 & 0.0135 & $0.106^{*}$ & $-\overline{-}$ & -0.331 & -0.0102 & $\begin{array}{c}0.0046 \\
3\end{array}$ & $\begin{array}{c}- \\
0.0523\end{array}$ & twitter_d \\
\hline
\end{tabular}




\begin{tabular}{|c|c|c|c|c|c|c|c|c|c|c|c|c|c|c|c|c|}
\hline$(-0.07)$ & $(0.98)$ & $(0.58)$ & (1.05) & $(0.09)$ & $(1.24)$ & $(-0.07)$ & $(-0.01)$ & $(-1.01)$ & $(0.08)$ & $(2.01)$ & $(-1.19)$ & $(-0.53)$ & $(-0.76)$ & $(0.28)$ & $(-0.68)$ & \\
\hline $\begin{array}{c}- \\
0.0084 \\
6\end{array}$ & $\begin{array}{c}- \\
0.0024 \\
1\end{array}$ & $\begin{array}{c}0.0024 \\
0\end{array}$ & $0.0130 *$ & $\begin{array}{c}- \\
0.0057 \\
9\end{array}$ & $\begin{array}{c}- \\
0.0046 \\
2\end{array}$ & $\begin{array}{c}- \\
0.0017 \\
3\end{array}$ & 0.00249 & 0.00161 & $\begin{array}{c}- \\
0.0001 \\
95\end{array}$ & 0.00577 & $\begin{array}{c}0.0022 \\
5\end{array}$ & $\begin{array}{c}- \\
0.0017 \\
2\end{array}$ & $\begin{array}{c}- \\
0.0012 \\
8\end{array}$ & $\begin{array}{c}- \\
0.0002 \\
15\end{array}$ & $\begin{array}{c}- \\
0.0064 \\
3\end{array}$ & sentiment_d \\
\hline$(-0.21)$ & $(-0.22)$ & $(0.31)$ & $(2.27)$ & $(-0.12)$ & $(-1.05)$ & $(-0.62)$ & $(-0.76)$ & $(0.64)$ & $(-0.01)$ & (1.28) & $(0.70)$ & $(-0.15)$ & $(-0.44)$ & $(-0.09)$ & $(-1.46)$ & \\
\hline $\begin{array}{c}- \\
0.0955\end{array}$ & 0.0136 & 0.0150 & -0.0435 & -0.140 & $\begin{array}{c}- \\
0.0471\end{array}$ & $\begin{array}{c}- \\
0.0749 \\
*\end{array}$ & 0.0874 & 0.00148 & $\begin{array}{c}- \\
0.0002 \\
69\end{array}$ & -0.0530 & 0.0634 & 0.283 & -0.0210 & -0.0573 & 0.0789 & $\begin{array}{l}\text { social_volu } \\
\text { me_d }\end{array}$ \\
\hline $\begin{array}{l}0.766^{*} \\
* * \\
(5.43)\end{array}$ & $\begin{array}{l}0.463 * \\
* * \\
(8.39)\end{array}$ & $\begin{array}{l}0.260 * \\
* * \\
(9.03)\end{array}$ & $\begin{array}{c}0.160 * * \\
* \\
(7.70)\end{array}$ & $\begin{array}{c}0.586 * \\
* * \\
(4.29)\end{array}$ & $\begin{array}{l}0.108 * \\
* * \\
(8.27)\end{array}$ & $\begin{array}{l}0.131 * \\
* * \\
(10.90)\end{array}$ & $\begin{array}{c}0.170 * * \\
* \\
(11.42)\end{array}$ & $\begin{array}{c}0.0662 * \\
* * \\
(8.43)\end{array}$ & $\begin{array}{c}0.424 * \\
* * \\
(7.78)\end{array}$ & $\begin{array}{c}0.0587 * \\
* * \\
(6.53)\end{array}$ & $\begin{array}{l}0.140 * \\
* * \\
(9.84)\end{array}$ & $\begin{array}{l}0.200 * \\
* * \\
(5.05)\end{array}$ & $\begin{array}{l}0.127 * \\
* * \\
(10.05)\end{array}$ & $\begin{array}{c}0.133 * \\
* * \\
(11.93)\end{array}$ & $\begin{array}{c}0.116^{*} \\
* * \\
(12.53)\end{array}$ & _cons \\
\hline 386 & 2468 & 5157 & 5494 & 897 & 5882 & 5329 & 4886 & 5793 & 1631 & 5900 & 4976 & 1689 & 4317 & 5761 & 5742 & $\mathrm{~N}$ \\
\hline
\end{tabular}

$\mathrm{t}$ statistics in parentheses

$* \mathrm{p}<0.05, * * \mathrm{p}<0.01, * * * \mathrm{p}<0.001$ 